Revista lus et Praxis, Año 23, № 1, 2017, pp. 579 - 626

ISSN 0717 - 2877

Universidad de Talca - Facultad de Ciencias Jurídicas y Sociales

El efecto de la sentencia condenatoria del procedimiento abreviado

en el juicio indemnizatorio por responsabilidad civil ex delicto

Ignacio Ried Undurraga

Trabajo recibido el 26 de agosto de 2015 y aprobado el 25 de abril de 2016

\title{
El efecto de la sentencia condenatoria del procedimiento abreviado en el juicio indemnizatorio por responsabilidad civil ex delicto
}

\author{
THE CRIMINAL CONVICTION OF THE PLEA BARGAINING
}

AND THE EFFECT IN THE CIVIL COMPENSANTION TRIAL

IGNACIO RIED UnDURRAGA*

Resumen

La sentencia condenatoria penal pronunciada en un juicio abreviado o en uno simplificado en que existió admisión de responsabilidad del imputado, no resulta una vía idónea para el descubrimiento de la verdad en el proceso y, por ello, no es aplicable la norma del art. 178 CPC que permite hacer valer la sentencia condenatoria penal en el juicio civil de indemnización de perjuicios. Esto, porque se trata de una verdad consensuada, no adversarial ni tampoco fruto de un juicio jurisdiccional. Sin embargo, la admisión de los hechos en el juicio abreviado, por parte del imputado, podrá ser considerada como una confesión extrajudicial en el proceso civil, bajo determinadas circunstancias.

\section{ABSTRACT}

The criminal conviction pronounced in an plea bargaining is not a suitable way to discover the truth in the process, and therefore not applicable provision $N^{\circ} 178$ of the Chilean Code of Civil Procedure, which allows to enforce the criminal conviction in the civil compensation trial. The conviction of the plea bargaining is a consensual truth, not adversarial, nor the result of a court judgment. However, the admission of the facts in the plea bargaining, by the accused, may be regarded as an extrajudicial confession in civil proceedings, under certain circumstances.

PaLABRAS ClAVE

Juicio abreviado, cosa juzgada, art. 178 CPC, verdad en el proceso, confesión extrajudicial.

KEYWORDS

Plea bargaining, res judicata, provision $N^{\circ} 178$ of the Chilean Code of Civil Procedure, procedural truth, extrajudicial confession.

\footnotetext{
* Abogado, licenciado en Derecho de la Pontificia Universidad Católica de Chile. Máster en Derecho Penal y Ciencias Penales de la Universidad de Barcelona y Universidad Pompeu Fabra, Barcelona, España. Profesor del curso de Litigación y Estrategia Civil de la Facultad de Derecho de la Universidad Diego Portales. Dirección postal: Av. Andrés Bello 2711, piso 8, comuna de Las Condes, Santiago. Correo electrónico: iried@bmaj.cl. El autor agradece los comentarios y aportes del profesor Aldo Mascareño Lara en la elaboración del capítulo $V$ de este trabajo.
} 


\section{Planteamiento del problema}

Los procedimientos abreviado y simplificado autorizan al Ministerio Público a negociar con el imputado y su defensa; el persecutor obtiene generalmente colaboración para la investigación -información importante, hechos reveladores respecto de otros imputados, una reparación a la víctima- y el imputado, a su vez, obtiene una rebaja en la pena que se solicitará aplicar. Muchas veces lo que se negocia por el imputado es una pena no privativa de libertad. Este intercambio, sin embargo, tiene un precio para ambos intervinientes. El Ministerio Público renuncia a la pena máxima que puede solicitar respecto del imputado que negocia; el imputado renuncia, a su vez, a su presunción de inocencia reconociendo los hechos o la responsabilidad materia de la investigación. Por su parte, el Tribunal de Garantía evita seguir adelante con el proceso, limitándose a dictar sentencia sobre la base de lo investigado por el Ministerio Público, de la pena pedida por éste, y del reconocimiento efectuado por el imputado. Se ahorran así recursos para el Estado, y el imputado evita tener que afrontar las consecuencias negativas que el proceso penal necesariamente ocasiona, siendo quizás la más importante la incertidumbre acerca de su resultado. El actual Código Procesal Penal, en sus artículos 406 a 415 , contempla entre muchas otras manifestaciones del principio de oportunidad, el juicio abreviado, esto es, el proceso seguido ante un juez de garantía, en que se dicta sentencia sólo con mérito de los antecedentes de la carpeta investigativa, una vez que el imputado ha reconocido los hechos, siempre que se trate de "hechos respecto de los cuales el fiscal requiriere la imposición de una pena privativa de libertad no superior a cinco años de presidio o reclusión menores en su grado máximo [entre tres años y un día y cinco años], o bien cualesquiera fuere su entidad o monto, ya fueren ellas únicas, conjuntas o alternativas" (art. 406 inc. $1^{\circ}$ CPP). Asimismo, el artículo 388 CPP contempla el procedimiento simplificado "respecto de los hechos constitutivos de simple delito para los cuales el Ministerio Público requiriere la imposición de una pena que no excediere de presidio o reclusión menores en su grado mínimo [entre sesenta y uno y quinientos cuarenta días]", respecto del cual el artículo 395 autoriza que el imputado admita su responsabilidad en los hechos, permitiendo incluso al fiscal modificar la pena requerida originalmente. En cualquier caso, esta admisión de responsabilidad obliga al juez de garantía a dictar sentencia inmediatamente, limitado por la pena solicitada en el requerimiento del fiscal. Si se comparan ambas normas, las diferencias saltan a la vista inmediatamente: el juicio abreviado procede respecto de delitos de mayor gravedad que el simplificado; y respecto del primero, el imputado sólo admite los hechos de la imputación, mientras que en el simplificado reconoce derechamente su responsabilidad. Esta última diferencia parece 
más aparente que real, desde que es el tribunal el único órgano competente para adjudicar responsabilidad penal a una persona, siendo indiferente que la persona la admita.

Estas importantes innovaciones procesales no estuvieron acompañadas, sin embargo, de una adecuación de la ley procesal civil que regula los efectos patrimoniales de la condena así obtenida para los efectos de establecerse una indemnización por la responsabilidad civil ex delicto.

En este trabajo se responderá a la siguiente pregunta: ¿puede la sentencia condenatoria penal en un juicio abreviado o en un simplificado, en que el imputado reconoce responsabilidad, ser invocada por la víctima del ilícito en un proceso civil diverso, para reclamar una reparación patrimonial que sea consecuencia del mismo, alegando el efecto de cosa juzgada? Desde ya adelanto que la respuesta a esta pregunta es negativa. Sin perjuicio de ello, se propondrá una validación de la admisión de los hechos o de responsabilidad -no de la condena- en el proceso civil, en el sentido de ser tenida como una confesión extrajudicial. Asimismo, se tratará el caso de los coimputados en los mismos hechos, y el efecto que genera la aprobación de un juicio abreviado sólo respecto de algunos de ellos. Respecto de todos estos temas, será pertinente revisar si es aplicable el art. 178 del CPC, que consagra para el proceso civil el efecto de cosa juzgada de la sentencia condenatoria penal, y hacer una revisión de la doctrina elaborada a propósito del juicio abreviado.

En la discusión parlamentaria del actual Código Procesal Penal se dejó intacto el régimen vigente sobre el efecto de las sentencias penales en el proceso civil, contenidas en el Código de Procedimiento Civil de 1903. Esta decisión resultó, en cierto modo, paradójica si se tiene en cuenta que el actor civil prácticamente fue expulsado del nuevo proceso penal. Esta marginación se manifestó en que, por un lado, se acotó el ejercicio de la acción civil sólo al juicio oral, según la norma del art. 393 inciso $2^{\circ} \mathrm{CPP}$, etapa procesal a la que arriba una ínfima parte de los procesos. Por otro lado, se redujo sustancialmente la nómina de posibles legitimados activos y pasivos de la acción civil, pudiendo sólo la víctima ejercerla y únicamente contra el imputado, como dispone el art. 59 CPP. Coherentemente con lo anterior, el art. 412 CPP in fine dispone lo siguiente: "la sentencia [del juicio abreviado] no se pronunciará sobre la demanda civil que hubiere sido interpuesta". Por otra parte, el inciso final del art. 413 CPP obliga al tribunal de garantía a disponer solamente el "comiso de los instrumentos o efectos del delito" o su

\footnotetext{
1 La norma es coherente con lo dispuesto en el art. 31 del Código Penal ("toda pena que se imponga por un crimen o un simple delito, lleva consigo la pérdida de los efectos que de él provengan y de los instrumentos con que se ejecutó, a menos que pertenezcan a un tercero no responsable del crimen o
} 
restitución, cuando fuere procedente", lo que implica que tanto la acción indemnizatoria de responsabilidad civil ex delicto -la que dimana del hecho dañoso que corresponde al ilícito penal- respecto del imputado como las restantes acciones restitutorias ${ }^{2} \mathrm{o}$ indemnizatorias contra terceros civilmente responsables deberán ser ejercidas en un proceso diverso. En el mismo sentido, el artículo 393 CPP inciso segundo dispone que "en el procedimiento simplificado no procederá la interposición de demandas civiles, salvo aquella que tuviere por objeto la restitución de la cosa o su valor". Aunque el tema se debatió escuetamente en el Parlamento ${ }^{3}$, la casi total expulsión del actor civil del proceso penal estuvo sustentada en razones de economía procesal y en garantizar que el imputado pudiera ser juzgado en un tiempo razonable, sin perjuicio de otras posibles consideraciones dogmáticas o históricas ${ }^{4}$. De cualquier forma, el divorcio entre competencias civiles y criminales para determinar las consecuencias civiles del ilícito penal, sumado a que el juicio abreviado suele concluir en forma muy anticipada a cualquier acción civil, generó un escenario en que existirá un fallo penal -casi siempre condenatorio- que podría tener algún valor en un proceso civil diverso, ante un tribunal con otra competencia que el que determinó la responsabilidad penal. La situación actual, entonces, es que el art. 68 CPP, tratándose del juicio abreviado, permite el ejercicio de la acción civil indemnizatoria ex delicto, siempre que se ejerza en un juicio civil (sumario) diverso, en concordancia con el nuevo texto del art. $680 \mathrm{~N}^{\circ} 10$ del $\mathrm{CPC}^{5}$.

simple delito"), cuyo contenido es prácticamente idéntico al del art. 348 CPP, referido al contenido de la sentencia definitiva del juicio oral. La interpretación coherente de los arts. 412 y 413 inciso final CPP permite concluir que el tribunal de garantía no se pronunciará sobre la acción civil restitutoria, pero sí debe de oficio ordenar la restitución de los efectos del delito a la víctima, lo que parece llevar al mismo resultado.

2 Entre otras, la acción de restitución del provecho del dolo ajeno del art. 2316 inciso segundo del Código Civil. CONTARDo (2015), pp. 139-140, hace un recuento exhaustivo de las acciones (pretensiones) restitutorias de fuente contractual existentes en el Código Civil, que sumarían veintidós hipótesis diferentes.

${ }^{3}$ Véase MARín (2005).

${ }^{4}$ Horvitz (2004b), p. 612; Rojas (2013), pp. 1-2.

${ }^{5}$ El art. $680 \mathrm{~N}^{\circ} 10$ del CPC fue reformado por la ley $\mathrm{N}^{\circ} 20.192$ de 2007, haciendo aplicable el juicio civil sumario "a los juicios en que se deduzcan las acciones civiles derivadas de un delito o cuasidelito, de conformidad con lo dispuesto en el artículo 59 del Código Procesal Penal y siempre que exista sentencia penal condenatoria ejecutoriada". 
La ley procesal civil chilena, en el artículo 178 CPC dispone: "en los juicios civiles podrán hacerse valer las sentencias dictadas en un proceso criminal, siempre que condenen al procesado". Esta norma es, a su vez, coherente con lo dispuesto en el art. 24 del Código Penal: "toda sentencia condenatoria en materia criminal lleva envuelta la obligación de pagar las costas, daños y perjuicios por parte de los autores, cómplices y encubridores y demás personas legalmente responsables". En el antiguo proceso penal vigente en Chile, la aplicación de estas normas no originaba mayores problemas, ya que el juez penal ostentaba una competencia adhesiva para conocer también de la acción civil $^{6}$. En el antiguo sistema, coherente con un apego irrestricto al principio de legalidad en la persecución penal, no existía tampoco una institución parecida al juicio abreviado, ni la admisión de responsabilidad, como sucede hoy en el juicio simplificado.

En este trabajo se sostendrá que no es correcto adjudicar a la sentencia condenatoria del juicio abreviado, o en un simplificado en que el imputado reconoce responsabilidad, el supuesto efecto de cosa juzgada del art. 178 CPC, atendiendo a los serios reparos que la doctrina latamente ha consignado como vía de descubrimiento de la verdad en el proceso penal, señalando que se trata simplemente de una "verdad negociada". Sin embargo, parece también claro que la aceptación de los hechos o de responsabilidad por parte del imputado debe tener algún efecto en el proceso civil, tanto respecto del imputado mismo como de terceros civilmente responsables. Si la confesión del imputado tiene una importancia tan relevante en sede penal -al punto de permitir condenarlo- parecen haber importantes razones también para asignarle un efecto en el juicio civil posterior. Ese efecto no será el de la cosa juzgada, por las razones que se explicarán, pero sí será el efecto de una confesión extrajudicial, que ponderada con las restantes probanzas, eventualmente podrán persuadir al juez civil de condenar patrimonialmente al imputado, como forma de mantener la coherencia entre los distintos fallos, que es por lo demás uno de los efectos buscados por la institución de la cosa juzgada.

${ }^{6}$ Véase Pizarro (2005). 


\section{La verdad negociada en el Código Procesal Penal ${ }^{7}$ y los reparos doctrinales}

Como sucede con varias instituciones propias del proceso penal, la admisión de hechos o de responsabilidad por el imputado han sido estigmatizadas por la doctrina garantista como conculcadores de ciertas garantías básicas y, por lo mismo, su resultado -la sentencia jurisdiccional-como un mero sucedáneo de la verdad, la que sólo podría alcanzarse a través del juicio oral. Por otra parte, existen voces más moderadas -o bien pragmáticas-que lo ven como una manifestación proporcionada del predominio del criterio eficientista que permite descongestionar el sistema penal de las infracciones leves, y reservar, por lo tanto, los escasos recursos estatatales sólo para los casos graves e importantes. La polémica ha estado centrada, naturalmente, en el juicio abreviado -más que en el simplificado en que se admite responsabilidad-, porque permite una salida alternativa para delitos especialmente graves. Así sucedió en los albores de la Reforma Procesal Penal a propósito del caso Jorge Lavandero Illanes (2005a), que realmente se trató del rol que jugó su abogado defensor ${ }^{8}$; aunque actualmente no existe mayor debate

\footnotetext{
7 El Código Procesal Penal incorporó el juicio abreviado y la admisión de responsabilidad en el simplificado, siguiendo la tendencia de varios otros países en esta materia. Las legislaciones comparadas más conocidas son la de Estados Unidos de América (plea bargaining), la de Italia (pattegiamento) y la española (conformidad). En este trabajo se hace referencia también al caso argentino. Respecto al plea bargaining, el Black's Law Dictionary de GARNeR (2004), p. 1190, lo define como "a negotiated agreement between a prosecutor and a criminal defendant whereby the defendant pleads guilty to a lesser offense or to one of multiple charges in exchange for some concession by the prosecutor, usually a more lenient sentence or a dismissal of the other charges". La regla 11 (e) (1) de las Federal Rules of Criminal Procedure de los EE.UU. dispone que "the attorney for the government and the attorney for the defendant or the defendant when acting pro se may engage in discussions with a view toward reaching an agreement". Rodríguez (1995), pp. 94-98, explica las distintas clases de acuerdos y el contenido que se le puede dar. GuZMÁn (2005), p. 298, aclara que el pattegiamento se incorporó al Código Procesal Penal italiano en el año 1988 (arts. 444 a 448, la "applicazione della pena su richiesta delle parti", o la aplicación de la pena a petición de las partes), que "sólo podía ser solicitada por el imputado y que requería la conformidad del fiscal para su aplicación. Consistía básicamente en una declaración de extinción del hecho investigado, y se sustituía la pena de prisión por otras sanciones (semidetención, libertad vigilada, sanción pecuniaria), sanciones estas que podrían ser consideradas como sustitutivas y que no perdían por ello su carácter de penales". En España se incorporó la institución de la conformidad a partir de la Ley 1/1988 que modificó la Ley de Enjuiciamiento Criminal, y que permite, según consigna BARONA (1994), p. 253, que el imputado manifieste su conformidad a modo de confesión en el acto del juicio oral por delitos graves, admitiendo los hechos y haciendo superflua la rendición de la prueba. También se contempla un juicio abreviado similar al nuestro, en que el imputado acepta los hechos de la acusación. En Alemania, Roxin (2001), p. 100, da cuenta del reconocimiento jurisprudencial de los acuerdos (absprache) a los que se llegaba en la práctica forense, intentando una aplicación coherente con los principios rectores del proceso (investigación, no autoincriminación, publicidad, inmediación, culpabilidad, procedimiento leal).

${ }^{8}$ En forma coetánea al inicio de la Reforma Procesal Penal en la Región Metropolitana, en junio de 2005, el caso Jorge Lavandero Illanes (2005a) parecía concluir con la sentencia del Tribunal de Garantía de Temuco, que aprobó el juicio abreviado pactado entre la defensa del entonces senador Jorge
} 
en nuestro medio acerca de su legitimidad, siendo aceptado por los operadores jurídicos y la ciudadanía como una alternativa válida de terminación de un proceso penal. Hay que decir que de cuando en cuando se levantan las voces de víctimas y querellantes que no quedan conformes con los acuerdos entre imputados y fiscales ${ }^{9}$, respecto de los cuales quien padeció el delito tiene sólo la facultad de manifestar su oposición, la que de cualquier forma no es vinculante para el juez de garantía que finalmente lo aprueba (art. 408 CPP, sólo en el caso del abreviado). No todos los estigmas en la doctrina comparada, respecto al juicio abreviado y al simplificado con admisión de responsabilidad, parecen ser extensivos al caso chileno. No existen en Chile, por varias razones de diseño institucional, fiscales que concluyan la abrumadora mayoría de los casos a través de negociación con el imputado, a quienes se presione indebidamente, como parece suceder en el sistema norteamericano ${ }^{10}$. En Chile, el juicio abreviado, y el simplificado en que el imputado admite responsabilidad, son sólo una "salida" más del sistema penal, y tampoco es de las más utilizadas, de acuerdo a cifras recientes ${ }^{11}$. Por lo

Lavandero, imputado por abusos sexuales, y el Ministerio Público. Los medios de comunicación social y la opinión pública siguieron muy de cerca el caso, en especial, cuando el senador ya condenado desconoció los términos del acuerdo alcanzado entre su defensa y el Ministerio Público, alegando haber sido presionado por su abogado defensor. Esto lo motivó a remover a su defensor, y contratar a un nueva defensa técnica particular, quienes apelaron de la decisión del Tribunal de Garantía. Sin embargo, la Corte de Apelaciones de Temuco no sólo decidió confirmar la decisión de primera instancia, sino además -ya que el Ministerio Público también había apelado- revocar los beneficios concedidos para el cumplimiento alternativo de la pena, según dispone la Ley № 18.216 (caso Jorge Lavandero Illanes (2005b)). A propósito del rol del abogado defensor en las negociaciones en el plea bargaining de EE.UU., MALLORD (2014), pp. 684-718.

${ }^{9}$ Nieva (2012), p. 217, quien además agrega la "incomprensión social" respecto del imputado que accede a un acuerdo, no debiendo cumplir una pena privativa de libertad o bien, cumpliendo una de corta duración en relación a la asignada al delito en la ley. En el mismo sentido, BerTOLINO (1999), p. 9, respecto de víctimas, querellantes y actores civiles, quien alude a la "tendencia de excluirlos en aras a la simplificación y celeridad".

10 Salas (2015), p. 281, ha dicho que el juicio abreviado se ha legitimado en el sistema chileno como consecuencia de los "méritos procesales de los operadores del sistema", en que existiría, a su juicio, "un Ministerio Público fuerte, pero a la vez, criterioso y respetuoso del principio de objetividad", "una Defensa Penal Pública independiente y respaldada funcional y económicamente por el Estado", "Jueces de Garantía atentos y dispuestos a velar por la vigencia de la normativa aplicable". En este sentido, "la Defensa suele no considerarlo [el juicio abreviado] un obstáculo en su camino, sino por el contrario, una opción interesante que, en caso alguno, excluye la posibilidad del juicio cuando existe la certeza relativa que su resultado pudiese ser más beneficioso para el imputado".

11 Las cifras citadas por SALAS (2015), p. 254, del año 2007, referían a que sólo un 20,93\% de las causas penales concluidas con sentencia de término lo eran por juicio abreviado. CociÑa (2012), p. 70, cita las estadísticas del Ministerio Público del año 2006, en que un 14\% de las causas concluían en procedimiento abreviado. Lamentablemente, el Boletín Anual publicado por el Ministerio Público no contiene un desglose de los procedimientos terminados por juicio abreviado. DuCE y RIEGO (2009), p. 191, en contraste, señalan que entre un $90 \%$ y un $95 \%$ de los casos son resueltos por la vía de 
mismo, es altamente probable que en la mayor parte de los casos el imputado que acepta los hechos es porque efectivamente entiende que alguna responsabilidad en ellos podría llegar a determinarse y, por otra parte, el fiscal asume que su caso no es tan "fuerte" como para soportar el estándar de un juicio oral, con el desgaste y la incertidumbre que ello significa ${ }^{12}$. Asimismo, creo que existe un error conceptual en el estigma de "inquisitivo" con que se tacha a estos juicios. En realidad, el juicio abreviado y el simplificado existen y funcionan dentro de un esquema perfectamente acusatorio, pero su déficit no es que el juez concentre la función de acusar y juzgar (que es el rasgo inherente del sistema inquisitivo) ${ }^{13}$. Su déficit es que no respeta el sistema adversarial, es decir, la verdad allegada al proceso no lo es por la contrastación de dos versiones contrapuestas, sino que surge de un acuerdo previamente resuelto entre las partes. Por esta razón es que muchos -me incluyo- son reticentes a hablar de que en este proceso se llegue a descubrir efectivamente la "verdad".

Dicho lo anterior, es necesario recoger, aunque sea sucintamente, las críticas de la doctrina, y en lo que nos interesa, en lo referido a que no es un medio idóneo para el descubrimiento de la verdad, como se expondrá en el capítulo V. Es por esta razón, como se verá, que no será posible extrapolar sus efectos al juicio civil que se ventile sobre los mismos hechos.

Como decía, la doctrina comparada adscrita al garantismo penal ha sido vehementemente crítica con estas innovaciones de la Reforma Procesal Penal. En la discusión legislativa parecen haber primado criterios de eficiencia o utilitaristas ${ }^{14}$ por sobre la garantía al juicio oral, en lo que se refiere a delitos de

negociaciones o plea bargaining entre imputado y fiscal en Estados Unidos de Norteamérica. Los mismos autores, p. 187, catalogan el modelo norteamericano como de una "discreción absoluta", en contraposición al modelo legalista, en que "no existe, por regla general, ningún mecanismo que obligue a los fiscales a llevar adelante una persecución penal que ellos no quieran impulsar". En este sentido, el plea bargaining y sus altísimas tasas de condena, p. 191, "ha potenciado una política criminal de carácter extremadamente represivo" en ese país. Para los autores el juicio abreviado sería una manifestación más, pero no la única, del principio de oportunidad o discrecionalidad propio del proceso penal chileno. Nieva (2012), p. 221, también señala que en EE.UU. un 90\% de los asuntos penales se resuelven vía negociación.

12 SAlAS (2015), pp. 253-254. Bigliani (2005), pp. 177-178, recoge, aunque no comparte, las ventajas consignadas en la doctrina norteamericana respecto de la evitación de la "pena procesal" que significa el juicio oral, "reduciéndose también la exposición pública del caso y acelerándose los tiempos del procedimiento". En el mismo sentido, NIEVA (2012), p. 219: "la conformidad es únicamente una forma de eludir los problemas que puede comportar un enjuiciamiento, es decir, no sólo una condena grave, sino que se revelen, a la postre, detalles de la vida privada que el reo, especialmente el reo inocente, no tiene ningún interés en divulgar. Además el reo se libra de la llamada "pena de banquillo".

13 ARMenta (2012), pp. 49-54.

14 En palabras de Vivas (1993), pp. 209 y ss.: "es un eficaz agente de economía de recursos temporales, procesales y financieros para el Estado de Derecho que se instaura a favor de los administrados orga- 
menor entidad, actualizando nuestra ley procesal a la tendencia mundial, cuyos ejemplos más conocidos son el plea bargaining de Estados Unidos de América, el patteggiamento italiano y la conformidad española, aunque con diferencias que es necesario tener en cuenta ${ }^{15}$. Como afirma Ferrajoli, "termina por justificar el sacrificio de las garantías en algunos procesos en aras de su satisfacción máxima en otros pocos"16. Si se tiene en cuenta que todo proceso penal implica el empleo de fondos públicos, parece razonable que el Estado, a través de una prerrogativa otorgada al imputado, sacrifique ciertas garantías procesales en beneficio de la sociedad toda $y$, en especial, de aquellos imputados por delitos especialmente graves, respecto de los cuales una renuncia de este tipo se haría insoportablemente

nizados judicialmente". Para CAFFERETA (1997), p. 87, "no se advierte que el juicio abreviado ponga en crisis el principio del debido proceso, pues las exigencias de éste se respetan. Hay acusación, defensa (que se ejercita a través de un reconocimiento de participación en el delito libremente formulada, y estimada conveniente a su interés por el imputado, debidamente asesorado por el defensor), prueba (la recibida en la investigación preparatoria estimada idónea por el Ministerio Público Fiscal, imputado, defensor y tribunal), sentencia (que se fundará en las pruebas de la investigación preparatoria -y en el corroborante reconocimiento de culpabilidad del acusado- y definirá el caso) y recursos (que procederán por las causales comunes". Asimismo, en el XIX Congreso Nacional de Derecho Procesal Argentino, citado por BerTolino (1999), p. 12, se señaló que los métodos del juicio abreviado "no son susceptibles de reparo porque procuran mitigar la morosidad judicial".

${ }^{15}$ La inspiración del juicio abreviado y simplificado previa admisión de responsabilidad parece estar, evidentemente, en dichos institutos muy reconocibles del derecho comparado, y así quedó consignado en la discusión legislativa. Sin embargo, es imprescindible tener en cuenta algunas diferencias importantes. Con el sistema español de la conformidad, GimENo (2010), p. 396, advierte que puede existir una "conformidad plena" que da lugar al "allanamiento-confesión" que "se proyecta no sólo sobre la petición de pena, sino también sobre los hechos que la fundamentan", y la "conformidad limitada" que da lugar al "allanamiento", sólo respecto de la petición de pena. Advierte este autor que en el juicio ante el jurado está permitido que la parte acusadora, el acusado y su abogado defensor suscriban un acuerdo, lo que "evoca claramente al plea bargaining americano". En detalle los alcances técnicos de la conformidad española en ARMENTA (2012), pp. 190-192. El sistema italiano, tal como lo detalla ToNINI (2015), pp. 725 y ss., es más complicado, y reconoce una serie de institutos procesales afines como el juicio abreviado, el ya aludido pattegiamento y el procedimiento de applicazione della pena su richiesta delle parti. En el abreviado, por ejemplo, el imputado está a la pena que el juez determine; en cambio, en el pattegiamento, sabe de antemano -porque la acordó- la pena a aplicar por el tribunal. ARMENTA (2012), p. 176, señala que el pattegiamento italiano presenta dos modalidades: el tradicional (se acuerda una pena sustitutiva de hasta dos años o una pena pecuniaria) y el allargato, introducido en 2003, "que permite el acuerdo por delitos reducidos en un tercio no superen los cinco años de pena detentativa y pena pecuniaria conjunta, estando acompañadas de causas de exclusión objetivas y supuestos de exclusión de beneficios". Maturana (2009), p. 227, consigna la discusión parlamentaria en que se dejó constancia la principal diferencia entre el sistema norteamericano ("se le pregunta al imputado si se declara culpable o inocente") y el europeo ("el imputado se mantiene como inocente pero acepta renunciar al juicio"). El proyecto chileno pretendió "combinar ambos sistemas". En la misma obra, p. 218, se consignó la opinión del profesor Bertolino: "en el sistema norteamericano pareciera que es un mecanismo para obtener una confesión, y paradójicamente aquí el juicio abreviado funciona, sin cazarme con la prueba confesional, cuando ya el imputado reconoció el hecho. Es un post, no un pre".

${ }^{16}$ FerRajoli (2009), p. 747. 
gravosa. En abstracto, esta idea no parece contraria a las concepciones liberales como la elaborada por John Rawl en su Teoría de la Justicia ${ }^{17}$.

Sin embargo, dogmáticamente, el juicio abreviado y el simplificado con admisión de responsabilidad parecen tener más detractores que defensores. Las objeciones principales pueden sintetizarse en los siguientes enunciados: (i) corresponde a un retroceso al procedimiento inquisitivo, en que es el mismo juez que controla la instrucción, quien finalmente falla el fondo del asunto ${ }^{18}$; (ii) se juzga y resuelve sobre la base de antecedentes que no son realmente prueba procesal, sino meras evidencias de la investigación; (iii) se juzga y resuelve sobre la base de la confesión del imputado, en circunstancias que la confesión no debiera tener mayor valor en nuestro sistema procesal penal ${ }^{19}$; (iv) la garantía de todo imputado al juicio oral se vuelve ilusoria ${ }^{20}$; (v) la confesión del imputado nunca es completamente libre y es consecuencia de una negociación poco transparente ${ }^{21}$; (vi) la sola aceptación de someterse a un juicio abreviado importa una condena automática.

\footnotetext{
17 RaWLS, John (2012), pp. 67 y ss.

18 Ferrajoli (2009), p. 747, advierte que este tipo de procedimientos "puede convertirse en una fuente de injusticias, aunque no sea más que porque, estando prevista incluso para delitos gravísimos castigados con reclusión perpetua, concluye en la audiencia preliminar ante un juez que quizá ya se ha pronunciado dictando un mandamiento de captura o rechazando una petición de archivo sobre la base de 'lo actuado' (art. 440.1), esto es, de elementos probatorios que, por definición legal (art. 526), no merecen el nombre de prueba". Como se advierte en esta cita, el sistema italiano que critica Ferrajoli permite que el imputado por cualquier delito -incluso los más graves- se acoja a este procedimiento, como explica Horvitz (2004b), pp. 506-507. Así lo consignó también la Asociación Nacional de Magistrados del Poder Judicial en la discusión parlamentaria: "Ilama la atención que en este caso se condene a una persona sobre la base de antecedentes que carecen de valor probatorio, y que la sentencia la dicte un juez que ha tenido conocimiento de los hechos, lo cual importa intromisión del rechazado sistema inquisitivo", en Maturana (2009), p. 218. En el mismo sentido lo consigna NúÑez (2003), p. 435, al referirse a la sesión 23a , de 13 de enero de 1998, de la Comisión de la Cámara de Diputados: "lo único que se hace es que, por vía del consentimiento del imputado, en el fondo, se está volviendo al sistema actual, el sistema sumario".

19 Ferajol (2012), p. 748, dice que este tipo de mecanismos procesales "puede generar perjuicios aún mayores de los que ha producido en el sistema americano, prestándose a actuar como instrumento de presión de autoacusaciones falsas, favoreciendo testimonios calumniosos por conveniencia, permitiendo obstruccionismos o prevaricaciones sobre la defensa, generando disparidad de tratamiento e inseguridad jurídica, rebajando, finalmente, el nivel, ya bajo, de la cultura judicial en materia de prueba". Armenta (2012), pp. 87-89.

${ }^{20}$ FerRAJOl (2012), p. 748, apunta que el juicio oral se transforma así en "un lujo reservado sólo a quienes estén dispuestos a afrontar sus costes y sus riesgos". ArmentA (2012), pp. 138-139: "el derecho al 'trial' sólo es realmente accesible a quienes pueden permitirse un buen abogado...".

${ }^{21}$ FerRAJOLI (2012), p. 749, señala que "el beneficio penal no será concedido por un juez en el transcurso de un juicio público sino por la misma acusación en el transcurso de una transacción destinada a desarrollarse en secreto".
} 
En lo que interesa en este trabajo, la objeción más relevante será que estos procedimientos no son un instrumento idóneo que permita fijar una verdad dotada de autoridad de cosa juzgada para irradiar a un proceso civil posterior. Como advirtió el profesor Pedro Bertolino en la discusión parlamentaria: "la verdad que me proporciona el juicio abreviado es una verdad práctica, es una verdad suficiente, es decir, con este al Estado le basta para solucionar el conflicto"22.

Las críticas al modelo anglosajón del plea bargaining han llegado a establecer un parangón entre la tortura como método de obtención de la confesión del imputado, respecto de la amenaza de ir a juicio, para obtener la aceptación de los cargos formulados por el persecutor estatal ${ }^{23}$. También en el sistema anglosajón, Alberto Bovino aclara que lo que el imputado hace a través del guilty plea "no es un elemento de prueba o una confesión, es en sí mismo una condena y tan determinante como el veredicto del jurado. Presentado el guilty plea, sólo resta la resolución judicial de condena (judgement of conviction), y posteriormente la determinación de la pena (sentence)"; en el mismo sentido señala que "la función del jurado en el juicio penal es determinar la cuestión de hecho acerca de la culpabilidad del acusado. Por ello, cuando el acusado admite su propia culpabilidad, el jurado se queda sin función alguna que cumplir y el juicio no se realiza" ${ }^{24}$. Armenta ha dicho que este tipo de acuerdos son manifestaciones del concepto de "justicia como administración" y de la "administración de justicia como gestión", que tiende a la resolución de grandes volúmenes de conflictos, aun a riesgo de basarse en el libre juego de las partes ${ }^{25}$, reparando, como hacen otros autores, que fue en EE.UU. donde las garantías para defensa habrían hecho demasiado oneroso para el Estado el aseguramiento de un juicio oral para todos, debiendo recurrirse a la fórmula de los acuerdos ${ }^{26}$. En Italia, Luigi Ferrajoli ha sido también un gran crítico del pattegiamento, abogando por un sinceramiento del sistema a través de la reforma del Código Penal en el sentido

22 Maturana (2009), p. 217; Bertolino (1999), p. 19.

23 LANGBein (2005), pp. 3-29.

${ }^{24}$ Bovino (2005), p. 60. Este autor acota, p. 79, con razón, que Argentina (y también Chile, hay que decirlo), a diferencia de Estados Unidos de América, son suscriptores del Pacto Internacional de Derechos Civiles y Políticos, cuyo art. 14 número 3 letra g) consagra el derecho de toda persona a no ser obligada a declarar contra sí misma ni a confesarse culpable, que el juicio abreviado contravendría. Asimismo, contrasta los resguardos que el legislador impone al tomar declaración al imputado ante las policías y el Ministerio Público (en que no puede tomarse juramento de decir verdad, no puede ser coaccionado, no debe aprovecharse de su cansancio, etc.) frente a lo que sucede al aceptar el juicio abreviado, en que-a juicio de este autor- esos resguardos desaparecen, sobre todo, porque la amenaza de ir a juicio oral sería una coacción en sí misma.

25 Armenta (2013), p. 240.

${ }^{26}$ Armenta (2013), p. 250. 
de rebajar las penas; esto, porque efectivamente el principio de oportunidad y las salidas alternativas corresponden a una forma indirecta de derogar o rebajar sustancialmente las penas asignadas a los distintos ilícitos en la ley sustantiva ${ }^{27}$, considerándolo de cualquier modo un resabio de aquella época en que la acusación era enteramente privada y, por lo mismo, negociable ${ }^{28}$. En el mismo sentido, Bigliani precisa que a través de este tipo de instituciones procesales lo que se vulnera es la garantía constitucional de legalidad de las penas ${ }^{29}$. Córdoba acota con razón que "más que de un juicio abreviado se trata, en realidad, de la supresión total del juicio"30, y en su opinión resulta inaceptable que "en lugar de buscar eficiencia recurriendo a mecanismos autorizados por las normas fundamentales, a través de un procedimiento acorde con el que ellas le imponen como condición para aplicar la ley penal, [el Estado] pretende solucionar la situación, de la que él mismo es responsable, trasladándole esa responsabilidad al imputado: si quiere un juicio rápido y poner fin a su prisión preventiva y a la situación de incertidumbre a la que está sometido, que renuncie entonces al juicio previo a cambio de una pena más leve" ${ }^{131}$; asimismo, "se afecta el principio de proporcionalidad entre el delito y pena, pues en este caso la pena depende de la conducta procesal del acusado y no de la gravedad del acto" ${ }^{\prime 32}$. Martina Cociña, en una reciente monografía sobre la verdad en el proceso penal, reconoce que la existencia de estos procesos negociados significa una resignación "frente a la necesidad inmediata de descongestionar el sistema", constatando que se trata de una restricción a la búsqueda de la verdad ${ }^{33}$.

\section{El art. 178 CPC y la verdad penal negociada}

De los autores nacionales que se han ocupado del efecto de los fallos penales en el juicio civil, con posterioridad a la entrada en vigencia de la Reforma Procesal Penal, Enrique Barros ha dicho que el sentido de la regla del art. 178

\footnotetext{
27 Ferrajol (2005), p. 49; Bertolino (1999), p. 2; Del Río (2008), pp. 171-175. Este último autor aclara que "dentro del ordenamiento chileno no cabe sino admitir una aplicación del principio del consenso de las partes respecto del rito procedimental, pero no sobre el mérito procesal [objeto del proceso], salvo de manera restringidísima en cuanto haya reconocimiento legal de efectos limitadores del marco punitivo". Señala que en Chile operaría un principio de oportunidad restringido, diferente al sistema amplio del modelo norteamericano, que da un mayor margen de discrecionalidad al fiscal.

28 Ferrajoli (2012), p. 748.

29 Bigliani (2005), p. 187.

${ }^{30}$ Córdoba (2005), p. 232.

31 CÓRDOBa (2005), pp. 241-242.

32 Córdoba (2005), p. 247.

33 CoCiña (2012), pp. 69-72.
} 
CPC es que "no puede el juez poner en duda la existencia del hecho que constituye el delito, ni la culpa del condenado", sin perjuicio de que deberá el actor civil acreditar el daño y la relación de causalidad con el ilícito ${ }^{34}$. Por su parte, Hernán Corral ha reconocido explícitamente que se trata de un efecto de cosa juzgada "respecto de la existencia del hecho y la culpabilidad del condenado" ${ }^{35}$. Alejandro Romero coincide en dotar a esta norma del efecto de cosa juzgada, aunque en un trabajo reciente ha manifestado sus aprensiones acerca de la coherencia de esta norma ${ }^{36}$. Todas las observaciones son tributarias del artículo

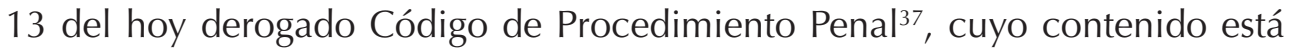
recogido en términos similares en el art. $180 \mathrm{CPC}^{38}$. Soledad Krause, en un texto reciente, también señala que se trata de un efecto de cosa juzgada "sui géneris", al no ser necesaria la exigencia de la triple identidad lega ${ }^{39}$. Sin embargo, en ninguno de estos textos existe una sola palabra destinada a resolver el problema del efecto en el proceso civil de la sentencia condenatoria del juicio abreviado y del simplificado en que el imputado reconoce su responsabilidad. Se trataría, en todo caso, de un efecto de cosa juzgada material, positivo y eventualmente ultra partes, si afecta a terceros ajenos al proceso penal, como se verá más adelante. El fallo penal actuaría como un presupuesto lógico o prejudicial que se integra a la norma de responsabilidad civil que se va a aplicar en el respectivo juicio posterior ${ }^{40}$. Se puede decir que los artículos 178 y 180 CPC desbordan tanto los límites objetivos como los subjetivos de la cosa juzgada.

Existe, sin embargo, un artículo científico del profesor Ruperto Pinochet ${ }^{41}$, en que trata específicamente el problema de la validez de la sentencia condenatoria

34 Barros (2008), p. 963. En el mismo sentido, Nieva (2012), p. 307.
35 Corral (2013), p. 50.
36 Romero (2011), p. 100. Romero (2015), pp. 467-468, citando a Carreras Llansana y Gómez Orbaneja,
cuestiona la lógica interna de un sistema en que se atribuye el efecto de cosa juzgada en el campo
civil a una sentencia condenatoria penal, "puesto que la calificación jurídico-penal de un hecho nada
tiene que ver con la calificación civil, de modo que, en rigor, una sentencia civil no puede depender en
cuanto a su contenido de que los hechos subsumidos en la norma civil sean o no constitutivos de delito".

37 Art. 13. Cuando el acusado hubiere sido condenado en el juicio criminal como responsable del delito, no podrá ponerse en duda, en el juicio civil, la existencia del hecho que constituya el delito, ni sostenerse la inculpabilidad del condenado. CASARINO (2005), p. 141.

38 Art. 180. Siempre que la sentencia criminal produzca cosa juzgada en juicio civil, no será lícito en éste tomar en consideración pruebas o alegaciones incompatibles con lo resuelto en dicha sentencia o con los hechos que le sirvan de necesario fundamento.

39 Krause (2015), p. 268.

40 Grande (2008), pp. 57-64; Rosende (2001), p. 496.

${ }^{41}$ PinOchet (2008), pp. 299-331. En contra de esta postura, la sentencia del Tribunal Constitucional del caso Eugenio Domínguez Delpiano y otros (2015), que calificó el problema como de "mera legalidad" (considerando $22^{\circ}$ ). 
de estos juicios penales al proceso civil posterior. La conclusión a la que arriba es que la sentencia penal no tendría valor en el juicio civil, porque en aquélla se vulneraría la garantía del debido proceso consagrada en la Constitución Política y tratados internacionales ratificados por Chile. Entre otras, el derecho a un tribunal imparcial y la presunción de inocencia. Comparto, obviamente, esa conclusión, como se expone en este trabajo. Sin embargo, creo que hay que hacer un matiz respecto del argumento que la sustenta: estas sentencias no pueden ser validadas en el juicio civil porque la verdad no ha sido descubierta en el primero, sino que es un simple acuerdo entre partes, visado por el tribunal. Adolece de los déficits de incertidumbre, adversariedad y jurisdiccionalidad que veremos más adelante. Es cierto que el irrespeto de las garantías fundamentales del imputado complota contra el descubrimiento de la verdad en el juicio abreviado, pero esa vulneración -si la hay- es sólo una causa mediata que impide ese traspaso de validez fuera del proceso penal. Por lo demás, si el juicio abreviado y el simplificado adoleciera de los problemas de constitucionalidad denunciados, la propia sentencia penal sería anulable, y ni siquiera sería válida en sí misma, ni qué decir ante un tribunal civil diverso.

Donde sí existen palabras más clarificadoras es en la doctrina española. Para Nieva, "la sentencia de conformidad hace cosa juzgada sobre el hecho de que conformidad se ha producido, no sobre los hechos imputados, que quedarán completamente imprejuzgados, porque de hecho, incluso aunque el proceso esté avanzado, la realidad es que no se ha dictado sentencia, y por tanto, no se han enjuiciado los hechos" ${ }^{\prime 2}$.

Respecto del proceso civil esta solución parece correcta, ya que efectivamente la labor jurisdiccional en el procedimiento penal negociado se agota en su mera aprobación, sin existir una revisión ni juzgamiento sobre el fondo del asunto. Esto lleva a una solución más razonable, como es que el actor civil deba acreditar en un nuevo proceso civil el ilícito, el daño y la relación causal, no pudiendo aprovechar el fallo penal ya pronunciado, sin perjuicio de lo que se dirá respecto del valor de la confesión extrajudicial.

La "verdad negociada" a la que se arriba a través del juicio abreviado y simplificado, luego de dictarse la sentencia, enfrentará el problema adicional de cómo traspasar o validar esa verdad al proceso civil, en orden a que produzca algún efecto. Para ello será necesario adentrarse en un tema poco tratado por la doctrina, como es el contenido del objeto del proceso penal, premisa básica para todas las construcciones de cosa juzgada e instituciones afines. Como dice Jordi Nieva: "existe cierto consenso hoy que para averiguar lo que es el objeto del juicio jurisdiccional simplemente hay que analizar el objeto de cada juicio

42 NieVA (2012), p. 222; NieVA (2006), p. 151. 
jurisdiccional. Parece una obviedad y una tautología, pero la conclusión es cierta. El objeto del juicio jurisdiccional no admite, en realidad, clasificaciones doctrinales, y hay que atender a cada caso concreto individualmente considerado. $\mathrm{Si}$ a partir de ahí se quiere hacer un esfuerzo adicional para encajar los datos que surjan del análisis de ese caso concreto dentro de las categorías doctrinales, hay que tener en cuenta, en primer lugar, que ello supone un esfuerzo considerable. $\mathrm{Y}$, en segundo lugar, se trata, sin duda, de un esfuerzo muy poco fructífero, por no decir completamente estéril"43. A pesar del pesimismo del profesor Nieva, en otro trabajo ${ }^{44}$ desarrollé una teoría comparativa entre el proceso civil y penal, que permite, con las naturales limitaciones del caso, efectuar un paralelo entre los elementos del delito civil y penal, a efectos de determinar si existen coincidencias relevantes, sobre los que no me explayaré en la presente investigación, precisamente, porque creo que la sentencia condenatoria pronunciada en estos procesos abreviados y simplificados, previa admisión de responsabilidad, no produce el efecto de cosa juzgada en sede civil.

Como enunciaba en la introducción, la primera pregunta que hay que hacerse es si resulta aplicable el art. 178 CPC, que no fue modificado por la Ley № 19.806 que estableció las normas adecuatorias del sistema legal chileno a la Reforma Procesal Penal: de ahí que se haya mantenido el anacronismo de referirse al "procesado", que ya no existe en el Código Procesal Penal ${ }^{45}$. Pero más allá de los problemas de nomenclatura -que pueden no ser irrelevantes en un proceso-, lo cierto es que cuando esta norma entró en vigencia, en el año 1903, no estaba en la mente del legislador el juicio abreviado ni el simplificado, que verían la luz casi cien años después, con la derogación del antiguo Código de Procedimiento Penal. Para esa ley procesal penal la sentencia condenatoria era una sola, y era la que se pronunciaba sobre el fondo, aplicando la pena. Los acuerdos a que arribaba el querellante con el imputado -que evidentemente existían-motivaban la terminación anticipada del proceso por el juez del crimen recurriendo a formas procesales como el sobreseimiento, que no reflejaban la realidad del pacto entre las partes. Y, al menos formalmente, los acuerdos entre el persecutor (el mismo juez del crimen) y el imputado estaban vedados.

El proyecto enviado por el Poder Ejecutivo a la Cámara de Diputados en el año 1995 incluía una expresa exclusión del efecto de cosa juzgada de la sentencia condenatoria emanada del procedimiento abreviado en el juicio civil. Así, el primitivo art. 473 de ese primer proyecto contenía una frase final

43 NieVA (2012), p. 25.

${ }^{44}$ Ried (2015), pp. 25-28.

45 PinOChet (2008), pp. 301-304, acerca de las modificaciones legales sufridas por este artículo, que originalmente empleaba la voz "reo". 
que disponía lo siguiente: "La sentencia condenatoria pronunciada en el procedimiento abreviado no producirá cosa juzgada en el juicio civil que se siga en contra del tercero civilmente responsable". Esta frase fue eliminada en el Senado, señalándose en las actas que "En lo que respecta al inciso cuarto, la Comisión mantuvo solamente la primera parte de la oración en el sentido que no se pronunciará sobre la demanda civil, y eliminó el resto porque esta situación se reguló en general en el artículo 69, para todos los casos en que el procedimiento se suspendiere o terminare anticipadamente. En la cual también se solucionan las cuestiones que podrían suscitarse sobre la interrupción de la prescripción. Todo ello en el ánimo de que el actor civil no se vea perjudicado por la aplicación del procedimiento abreviado". El problema surge porque el artículo 69, que motivó la eliminación de esta frase final referida al efecto de cosa juzgada, también fue eliminado posteriormente. Ese artículo 69 (similar al art. 87 del Código Procesal Penal Modelo para Iberoamérica) establecía la preclusión de las acciones civiles en el proceso penal, cuando este último terminaba por cualquier causa, dejando abierta la posibilidad que la acción civil fuera intentada ante un juzgado civil ${ }^{46}$. Existiendo esa norma del artículo 69 -que consagraba una mera preclusión de la acción civil cuando concluía el proceso penal, dejando indemne su ejercicio posterior- parecía superfluo que otra norma declarara expresamente que la condena dictada en el juicio abreviado no producía cosa juzgada civil.

Sin embargo, ese efecto preclusivo fue eliminado, dejando en una nebulosa cuál sería el efecto de la sanción penal en el futuro juicio civil, materia que en ese entonces estaba regulada (igual que hoy) en el art. 178 CPC, que no admite excepciones -toda condena penal produce efecto de cosa juzgada civil. Al consignarse en la historia de la ley la eliminación expresa de esta referencia a la negativa del efecto de cosa juzgada, surge la legítima inquietud de si, contrario sensu, la intención del legislador no era realmente otra que la condena del juicio abreviado sí produjera cosa juzgada en el proceso civil. Sin embargo, parece evidente que esta eliminación y la posterior omisión en su reposición explícita o implícita, se debió a un descuido, ya que tampoco existe en la historia de la ley ni en la doctrina referencia alguna que permita concluir que la intención del legislador era esa.

\footnotetext{
${ }^{46}$ Artículo 69.- Preclusión en el procedimiento penal. La demanda civil o las medidas destinadas a prepararla sólo podrán ser ejercidas en el procedimiento penal mientras se encuentre pendiente la persecución penal. Si se hubiere presentado demanda civil o solicitado alguna medida para su preparación en el procedimiento penal y éste se suspendiere o terminare anticipadamente por cualquier causa sin decisión acerca de la cuestión, el actor civil podrá ocurrir ate el tribunal competente. En MaturanA (2009), p. 252, la discusión sobre la eliminación del inciso final del art. 473 que establecía que el fallo penal del juicio abreviado no producía cosa juzgada civil respecto de terceros civilmente responsables.
} 
Parece existir, entonces, una paradoja en nuestro sistema, en que colisiona el efecto de cosa juzgada positiva y eventualmente ultra partes de la sentencia penal condenatoria con los déficits de verdad que más adelante se apuntarán respecto del fallo del juicio abreviado y del simplificado previa admisión de responsabilidad. Es el choque entre (i) la pretensión de seguridad y certeza jurídica de la sentencia firme con (ii) la obtención de la verdad en el proceso ${ }^{47}$. Siendo la cosa juzgada positiva una institución eminentemente práctica, de carácter más político que jurídico ${ }^{48}$, es posible revisar críticamente, como se hace en este trabajo, si dicho principio admite excepciones, como sucede con estas sentencias penales respecto del proceso civil. Hay que hacer una distinción: la cosa juzgada negativa, como manifestación del non bis in idem, está inserta en la garantía del debido proceso del art. 19 № 3 de la Constitución Política de la República y, en ese sentido, parece existir un argumento fuerte a favor de la estabilidad de los pronunciamientos judiciales cuando ésta pugna con la justicia de la decisión. Por otra parte, la prejudicialidad o cosa juzgada positiva -que no implica un doble juzgamiento de lo mismo- podría en cambio eventualmente ceder frente a la injusticia que encierra la validación de sentencias penales previas, si éstas adolecen de los déficits de verdad, como se expone en este trabajo, y sobre todo si terminan por afectar a terceros ajenos al proceso penal.

\section{La verdad en el proceso penal}

Antes de argumentar cómo es que estas sentencias penales negociadas no son una vía idónea para descubrir la verdad en el proceso, corresponde detenerse, aunque sea brevemente, en qué es la verdad en el proceso penal. Partiré asumiendo las premisas de que la verdad existe y de que uno de los fines del proceso penal es alcanzarla ${ }^{49}$. Desde ya diré que ningún proceso jurisdiccional es un instrumento perfectamente idóneo para alcanzar la verdad. Ciertamente el

\footnotetext{
47 Couture (2014), p. 330: "la necesidad de firmeza debe ceder, en determinadas condiciones, ante la necesidad de que triunfe la verdad". En el mismo sentido, Grande (2008), p. 46. En contra, Pereira (1984), quien le asigna valor de principio constitucional, sobre todo referido a la intromisión de otros poderes del Estado en los fallos civiles.

${ }^{48}$ Couture (2014), p. 332.

${ }^{49}$ Véase CociÑa (2012), pp. 25-47. La búsqueda de la verdad como fin del proceso no es un tema explícito en alguna doctrina. Así, SerRA (1969), p. 357, quien señalaba que "lo lógico hubiera sido abandonar para siempre el concepto de verdad como fin de la prueba jurídica y buscar por otros senderos el hallazgo de la solución". También Cоцомво (2014), pp. 122-124, señala que se trata de un mecanismo de resolución de conflictos, según consagra el artículo 73 de la Constitución Política de la República. PIÑA (2014), p. 274, dice también en clave jakobsiana que "la función manifiesta del proceso es la solución del conflicto penal, mientras que la función latente es la obtención de la decisión penal y la fijación del Derecho vigente".
} 
proceso civil y el juicio oral penal no lo son, y de hecho es muy probable que en muchos juicios civiles y penales dicha verdad nunca se alcance. Sin embargo, esos procesos al menos tienen el potencial de generar un conocimiento veraz de la realidad, lo que no ocurre en el juicio abreviado y en el simplificado, previa admisión de responsabilidad.

La verdad en el proceso penal presenta dos notas características: (1) se trata de una verdad extremadamente restringida por las garantías sustantivas y procesales, y (2) se trata de una verdad esencialmente comunicativa.

\section{Carácter restringido}

La verdad que es relevante para el proceso penal viene previamente restringida por la ley sustantiva que describe la conducta típica, como también por la forma en que dicha verdad puede ser obtenida y finalmente acreditada en el proceso, en que deben respetarse las garantías del imputado. El Derecho penal sustantivo selecciona, de entre las infinitas conductas humanas posibles, un catálogo muy acotado de ellas que son ataques especialmente graves a ciertos bienes jurídicos. Este ejercicio del legislador "sustantivo" es en sí mismo una reducción importante de la "realidad" que deberá ser considerada ${ }^{50}$. A su vez, la descripción típica contenida en la ley deberá acreditarse en el proceso ${ }^{51}$; por

\footnotetext{
50 Hassemer (1984), p. 147. Maier (1989), pp. 574-579, acerca del principio del nullum crimen, nulla poena sine lege, y la "indiferencia jurídica" del Derecho penal respecto de la casi totalidad de los comportamientos humanos. MARTín PASTOR (2013), p. 159, señala que "el objeto del proceso penal no es una pretensión procesal, sino un hecho punible que se atribuye a la persona acusada". HASSEMER (2009), p. 18, apunta que "los resultados que nos brinda la justicia penal no son adecuados para representarnos de manera fiel lo sucedido. Los resultados que nos brinda son demasiado selectivos y la explicación que la justicia penal nos da de estos, siguen completamente otro guión al de la investigación histórica (como ciencia social). La sonda de la justicia penal no se rige por el suceso sino por los elementos del tipo penal: los cuales constituyen sólo una partícula del suceso".

51 Mañalich (2014), p. 553; MAÑALICH (2011), p. 157. El autor señala que no es posible identificar el concepto jurídico-penal del hecho (entendido como la realización imputable de un determinado tipo delictivo) con el concepto procesal del hecho, ya que este último sólo se establecería definitivamente con la sentencia firme condenatoria. El concepto procesal del hecho estaría dado por una concepción normativo-fáctica (una suerte de "teoría de la sustanciación" procesal), que "si bien atribuye relevancia a los criterios relativos al tiempo y lugar de los acontecimientos, y al objeto de su incidencia, postula la necesidad de recurrir también a criterios "normativamente cargados", tales como la "dirección de ataque", la conmensurabilidad de los respectivos contenidos de ilicitud, la correspondencia de significación jurídico-penal de los diferentes tipos delictivos eventualmente realizados, entre otros". En mi opinión, el concepto de delito es uno solo, tanto para el derecho penal como procesal penal, sin perjuicio del uso que pueda hacerse del término en contextos por completo distintos. Es cierto, como acota el autor, que para el Derecho penal el delito es la descripción de la realización de una acción; en el proceso penal se utiliza la misma descripción, pero a través de un acto del habla performativo, como es una imputación (formalización de la investigación, acusación, condena). La descripción neutra del Código Penal es utilizada a través de un "juego del lenguaje" completamente distinto en la sentencia
} 
lo tanto, la verdad a que se arribará será necesariamente jurisdiccional, por lo mismo incierta y fruto de la confrontación adversarial de las partes. A ella sólo se puede llegar a través de ciertas formas y ritualidades preestablecidas, limitadas enormemente por las garantías fundamentalmente reconocidas del imputado (entre ellas, el derecho a no autoincriminarse). No toda realidad importa para la ley penal, sino sólo la conducta descrita en el tipo ${ }^{52}$. Y no cualquier forma de acreditar ese tipo penal sirve para el proceso, sino sólo en la medida que no se vulneren las garantías del imputado ${ }^{53}$. Es más: ni aun respetándose estas garantías en la acreditación de los hechos constitutivos del tipo penal, la tarea estará completa; si el juez alberga una duda razonable respecto de la responsabilidad del sujeto, deberá absolverlo, aun cuando disponga de cuantiosos antecedentes que -en otro contexto, ante la opinión pública, o en un juicio político- servirían para condenarlo ${ }^{54}$. Por el contrario, si existe el convencimiento de culpabilidad, el juez sólo puede razonar aplicando las máximas de la experiencia, los principios lógicos y los conocimientos científicamente afianzados ${ }^{55}$. Finalmente, y siguiendo a Hassemer, puede decirse que el efecto

o en la acusación. Asimismo, el delito como descripción neutra admite otros usos, el más recurrido por la literatura jurídica (Hart, entre otros) es su uso como norma primaria de conducta dirigida al ciudadano, como una orden de abstenerse de hacer algo. El delito, como construcción abstracta que es, existe tanto en la ley sustantiva que lo describe, como en la formulación de cargos, y en la condena. Y si es absuelto el imputado, con mayor razón debe tenerse en cuenta los tipos penales imputados para no incurrir en un doble juzgamiento o doble condena posterior.

52 Como acota González LaGier (2013), pp. 104-106: “Un hecho puede existir bajo un esquema conceptual y no existir bajo otro. La teoría de la verdad como correspondencia debe ser reinterpretada: sólo hay correspondencias una vez aceptado un esquema conceptual". Citando la obra de Putnam, el mismo autor aclara que "aunque existe un mundo 'objetivo', éste no posee una estructura ontológica dada, sino que ésta es construida con nuestros esquemas conceptuales: 'nosotros cortamos el mundo en objetos cuando introducimos uno u otro esquema de descripción'". Si bien el sistema de Derecho construye una realidad independiente del resto de los sistemas, como afirmaba Niklas Luhmann en una entrevista en el año 1973, decía González LaGier (2013), p. 108: "el Derecho no puede construir conceptos totalmente desconectados de otros esquemas conceptuales: lo que entiendan por intención o por causalidad los juristas no puede ser algo irreconocible desde el punto de vista del lenguaje común". En el proceso esto resulta particularmente cierto, si tomamos en cuenta que las evidencias y pruebas que se recolectan y rinden, respectivamente, son muchas veces elaboradas por personas ajenas al sistema, o que interactúan en sus márgenes.

53 Hassemer (1984), p. 188. Maier (1989), pp. 433-471.

${ }^{54}$ Art. 340 CPP. GONZÁlez LAGIER (2013), p. 93: "podría decirse que la presunción de inocencia es una garantía epistemológica parcial (de la verdad de la acusación, pero no de la verdad de la absolución) como medio para satisfacer una finalidad ulterior de un tipo distinto (práctica)". NIEVA (2012), p. 279, califica esto como una "solución antiepistémica", "dado que el hecho que no hayan aparecido pruebas no quiere decir, en la realidad, que una persona no sea responsable de un hecho". En el mismo sentido, Nieva (2013), p. 52.

55 Art. 297 CPP. 
de cosa juzgada, nota característica del juicio jurisdiccional (que en materia penal adquiere la dimensión de garantía del non bis in idem), complota contra la búsqueda de una verdad a ultranza, ya que en algún momento del proceso existirá una sentencia de término que fije para siempre lo que sucedió, impidiendo nuevas indagaciones o reaperturas del caso.

Recapitulando, puede decirse que la búsqueda de la verdad en el proceso penal está sometida al menos, a cinco filtros: (i) tipo penal, (ii) derechos del imputado en la obtención de la evidencia y en la rendición de la prueba, (iii) duda razonable y presunción de inocencia, (iv) normas de apreciación de la prueba, en caso de condena, y (v) cosa juzgada. Esto, sin perjuicio de que existen otras limitaciones que son propias del proceso penal, como es la posibilidad de que las partes arriben a convenciones probatorias (art. 275 CPP), la prohibición de que el juez ordene o produzca prueba de oficio, como sí sucede, por ejemplo, en el proceso penal español, como tampoco puede intervenir en la determinación del thema probandi, como sí se permite en el sistema italiano, etc. ${ }^{56}$. Esto motiva el pesimismo de muchos autores de que a través del juicio penal pueda obtenerse la "verdad" o determinarse la "realidad". Pero esto no significa que no exista una verdad que el proceso sea capaz de descubrir, o que no exista tal cosa como la verdad. Comparto con Ferrajoli que existe una verdad-correspondencia ${ }^{57}$, como "núcleo duro de la realidad", pero existen métodos de comprobación de esa verdad, a través de la "verdad-coherencia" y "verdad-aceptabilidad"58. Para Maier, por su parte, la verdad real serviría como sustento político del sistema inquisitivo para relegar las garantías del individuo en la medida que sea necesario para reconstruirla históricamente; o dicho de otra forma, en el Estado de Derecho moderno, la obtención de la verdad sólo es posible en la medida en que se respeten las garantías básicas del ciudadano, lo que, en palabras de Montero Aroca, implica una necesaria relativización de la misma ${ }^{59}$. Hassemer, por su parte, apela a una "obtención formalizada de la verdad", que sería finalmente, según Rodríguez, "el único objeto del proceso";

\footnotetext{
56 Puede pensarse en otras limitantes adicionales, como es la legitimación activa del Ministerio Público, que está acotada a los delitos de acción penal pública, pero que requiere de la actividad procesal de terceros en los delitos de acción pública previa instancia particular-como son los delitos tributarios, por ejemplo. Asimismo, la legitimación del querellante particular respecto de los delitos de acción penal privada, que es la única vía de iniciar ese tipo de procesos. O también que sólo interesará investigar aquellos delitos cuya acción no esté prescrita, entre otras limitantes propias del proceso.

57 Guzmán (2005), p. 282.

58 Rodríguez (2005), p. 4. González LaGier (2013), p. 94, refiere a esta teoría como el cognoscitivismo.

59 Montero (2011), p. 43. Guzmán (2005), p. 278, citando a Maier (1999), p. 852. El mismo Maier (1989), p. 573, aclara que para él la verdad objetiva (histórica) es un mero "ideal", y que el procedimiento penal alcanza su objetivo, aun cuando ese ideal nunca se logre concretar.
} 
esto es, una "verdad aceptabilidad", obtenida del diálogo y confrontación procesal y, por lo mismo, sería no una realidad históricamente construida, sino intersubjetiva. Estas posturas parten, por tanto, de posiciones contrapuestas respecto de la existencia de una "verdad real" o "verdad-correspondencia". Si para Ferrajoli ésta efectivamente existe, para Hassemer ello no es asín ${ }^{60}$. Interesante resulta la sistematización de Mañalich al atribuir al proceso penal tres funciones: una función de verdad, una función de justicia formal y una función de certeza jurídica, esta última, rasgo distintivo del juicio jurisdiccional, en orden a concluir definitivamente y para siempre la disputa, a través del efecto de cosa juzgada ${ }^{61}$. En ese orden de ideas, la función de verdad necesariamente colisiona con la función de certeza jurídica (non bis in idem), como he anotado más arriba, prevaleciendo en general la segunda. En relación a esto, en este trabajo se argumenta a favor de una excepción a la cosa juzgada positiva, precisamente, para dar prevalencia a la verdad.

Para Langer, por su parte, el juicio abreviado correspondería a un rasgo plenamente inquisitivo, orientado a "obtener reconocimientos de culpabilidad coactivamente", según un análisis funcional ${ }^{62}$ y, por lo mismo, cuyo objetivo sería la obtención de una supuesta verdad "como correspondencia" (con la realidad) que sólo el sujeto puede proveer (lo que es a lo menos discutible), y por lo mismo, ajeno por completo a la idea de la "verdad como garantía" elaborado por Luigi Ferrajoli ${ }^{63}$. Bigliani acota que "el juicio abreviado constituye el franco abandono, para supuestos gravísimos, de la categoría verdad-correspondencia, firmemente arraigada a nuestra tradición jurídica, y la sumisión al principio de verdad consensuada, ajeno a nuestra ideología" ${ }^{\prime 64}$. Hassemer ha dicho, sin ir

\footnotetext{
60 HaSSemer (1984), pp. 182-191. Se refiere a las hipótesis elaboradas por la biología, física, antropología, psicología y sociología, en que se tiene por verdaderas "aquellas tesis que han superado con éxito numerosos intentos de demostrar su falsedad y con modestia se las denomina tesis confirmadas". Pero ni aun estas tesis confirmadas gozan de permanencia en el tiempo, ya que la labor científica es precisamente someter cada hipótesis a sucesivas críticas y comprobaciones, que finalmente es la única forma en que el conocimiento avance. Por el contrario, a través del proceso se pretende justamente lo contrario: no eternizar las discusiones, sino dar al fallo el valor de permanencia a través de la cosa juzgada. Así, para Hassemer "al proceso penal se le dota de instrumentos para detener la búsqueda de la verdad".

${ }^{61}$ MaÑalich (2011), p. 149. Respecto de la función de certeza jurídica, también la interesante comparación que hace HASSEMER (1984), p. 186, con las discusiones científicas.

62 LANGer (2005), p. 107. Aunque este análisis funcional puede sonar correcto, concuerdo con Nieva (2012), p. 4, en que la nota característica del sistema inquisitivo era el doble rol del juez como acusador y juzgador, siendo la tortura y coacciones para obtener confesiones, un mero vicio del sistema, que también podría darse en los sistemas acusatorios.

63 LANGer (2005), p. 119.

${ }^{64}$ Bigliani (2005), p. 187.
} 
más lejos, que "la práctica de la conciliación trae consigo que el proceso penal alemán prácticamente prescinde de la búsqueda de la verdad (...) vulnera el 'Ethos' de la búsqueda de la verdad". La "verdad es para la conciliación perjudicial, pues la lógica de la conciliación es precisamente evitar esa búsqueda"65.

\section{Carácter comunicativo}

Siendo el proceso una sucesión de actos y situaciones eminentemente comunicativas, no debiera sorprender que la verdad que de él se obtiene también lo sea. La verdad en el proceso se predica no de los hechos que tuvieron lugar en la "realidad", sino de los enunciados contenidos en la pretensión acusatoria o en la teoría del caso de la defensa, referidos necesariamente a un tipo o tipos penales concretos. Los enunciados pueden estar compuestos no sólo de la referencia a ciertos fenómenos físicos o el despliegue de energía del sujeto enjuiciado, sino también respecto de "realidades" no históricas y que es imposible percibir directamente por los sentidos, como la disposición psicológica del sujeto que actuó dolosamente, o de términos derechamente normativos, que abundan en los tipos penales. Los enunciados, entonces, podrían ser verdaderos o falsos, según su correspondencia o no con el mundo. Pero aun esta idea es -valga la paradoja- una "verdad a medias", ya que no es cierto que todos los enunciados estén destinados a tener una exacta correspondencia (descriptiva) con un cierto fenómeno fáctico que sucede en el mundo, como alguna vez propuso el Wittgenstein positivista-lógico del Tractatus Logico-Philosophicus ${ }^{66}$. En realidad, los enunciados propios de la comunicación humana, incluidos por cierto los propios del juicio penal, suelen venir envueltos en "juegos del lenguaje" que no pueden reducirse a la mera descripción de un hecho, como avizorara -y se contradijera- el mismo autor en sus Investigaciones Filosóficas ${ }^{67}$. En este sentido, una imputación penal al comienzo del juicio oral es más parecido a una

\footnotetext{
${ }^{65}$ HaSsemer (2009), pp. 11-13.

${ }^{66}$ Wittgenstein (2014), p. 57. Arranca este autor su obra diciendo que "el mundo es todo lo que es el caso. El mundo es la totalidad de los hechos, no de las cosas. El mundo viene determinado por los hechos, y por ser éstos todos los hechos. Porque la totalidad de los hechos determina lo que es el caso y también todo cuanto no es el caso".

${ }^{67}$ WiTTGENSTEIN (2012), p. 41: "es interesante comparar la multiplicidad de herramientas del lenguaje y de sus modos de empleo, la multiplicidad de géneros de palabras y oraciones, con lo que los lógicos han dicho sobre la estructura del lenguaje. (Incluyendo al autor del Tractatus lógico-philosophicus)". A este respecto, CORDUA (2013), p 189: "la pretensión de poseer verdades absolutamente necesarias, esto es, que signifiquen lo mismo siempre, aparte de todo contexto, y cuyo significado es inalterable por las aplicaciones que se puedan hacer de ellas, es una pretensión vacua basada en varias confusiones que se combinan: por una parte, se confunde a la ciencia con el cálculo, o al conocimiento expresado proposicionalmente con las oraciones que expresa normas y reglas".
} 
promesa que el fiscal debe cumplir al tribunal, y no sólo a una descripción de un suceso acaecido en el pasado. Es, por tanto, un enunciado performativo, en la terminología de Austin ${ }^{68}$. Asimismo, los enunciados de una acusación penal contienen necesariamente una adjudicación que el juez debe efectuar, es decir, parece ser una invitación, o una forma de persuadir a un tercero para que haga algo, en este caso, condenar. Lo mismo puede decirse de las alegaciones de la defensa ${ }^{69}$. Es la propia ley la que obliga al juez a ser congruente en su sentencia con los hechos expuestos en la acusación; o sea, no hay un descubrimiento natural de la verdad, sino constreñido al acto comunicativo del fiscal. En suma, la verdad del proceso penal es inseparable del contexto en que se invoca.

Por todas estas razones, la idea propia del sistema inquisitivo de una verdad-correspondencia, esto es, de un ajuste del enunciado al mundo parece no servir en el proceso ${ }^{70}$. Dicho de otro modo: si la verdad fuera un fenómeno estático, descubrible por sí mismo por el investigador penal, sería superfluo que existiera un fiscal que "prometiera" en su alegato de apertura que "acreditará" todos y cada uno de los elementos del tipo penal infringido; también serían innecesarios los esfuerzos de la defensa por destruir el caso de la fiscalía, como también lo sería que la obligación del juez de exteriorizar su razonamiento a través de su sentencia. Si la verdad "está ahí afuera", lista para ser descubierta, no sería necesario una confrontación procesal ni menos que un juez finalmente la declarara. Todas estas actuaciones: las "promesas" de las imputaciones, el esfuerzo durante el proceso para rendir la prueba y el despliegue de razonamientos en la sentencia son esencialmente actos de comunicación entre distintos interlocutores, que hacen de la verdad no una simple descripción de un hecho acaecido en el mundo, sino que aspira a ser una correspondencia razonada entre los enunciados normativos y acusatorios y la prueba del proceso (la que

\footnotetext{
${ }^{68}$ Austin (2014), pp. 45-56.

${ }^{69}$ NIEVA (2012), pp. 290-291, aclara con bastante lucidez que el juez no hace realmente un razonamiento deductivo libre en su sentencia, sino que éste viene condicionado necesariamente por el contenido de la acusación y las alegaciones de la defensa. Por tanto, lo que tiene en frente no es simplemente una realidad presta a ser descubierta, sino sólo dos hipótesis concretas y contrapuestas. NievA (2013), p. 25, agrega que esta inducción que hace el juez a partir de la hipótesis acusadora encierra la paradoja de que el Derecho a aplicar ya viene contenido en la pretensión del fiscal, quien aún no ha acreditado los hechos sobre los que se aplica. Por tanto, no es que el juez vaya deduciendo los hechos a partir de la prueba rendida en el juicio para finalmente aplicar la norma, sino que, al contrario, induce los hechos a partir de una imputación penal concreta, que ya incorpora una aplicación normativa determinada.

70 Todo lo dicho, sin contar con otras complejidades propias anotadas por la doctrina. Así, Rodrí́Guez (2005), p. 11, se pregunta: "El relato penal de un hecho del pasado ireconstruye o construye? Cuando el testigo opera su descripción de lo que ha visto, ¿meramente describe o interpreta? Y en la interpretación, ¿acaso no crea? Cuando el juez hace, a su vez, metalenguaje de lo dicho por los testigos, y así compone su relato, ¿meramente describe o interpreta? Y en la interpretación, ¿acaso no crea?".
} 
a su vez, refiere a la realidad de los hechos). La verdad necesita ser comunicada: prometida, acreditada, razonada, fallada, constituyendo finalmente un fenómeno comunicativo en sí mismo. El fiscal no señala simplemente una "verdad" que el juez debe apreciar; por el contrario, el fiscal enuncia y comunica una determinada verdad de la que debe persuadir al juez ${ }^{71}$. Y aún más: el tipo penal-que es la primera limitante de la verdad en el proceso- tampoco puede considerarse como la mera descripción neutra de cierta conducta humana, que el juez simplemente contrasta con la prueba rendida en el proceso, adjudicándola mediante un simple silogismo. El tipo penal está indisolublemente ligado al uso que de él se hace en el lenguaje, a la forma de vida en que está inserto. La letra de la ley, estática, general, abstracta, cobra vida en la sentencia del juez y no lo hace como una simple premisa silogística.

\section{Los acuerdos entre fiscal e imputado como forma inidónea para la determinación de la verdad}

Hay que aclarar que el proceso civil está muy lejos de ser un instrumento idóneo para el descubrimiento de la verdad de los hechos. En Chile aún está vigente un procedimiento escrito y anticuado, con un sinnúmero de problemas que no es del caso detallar en estas líneas. Sin embargo, y aun tomando en cuenta sus carencias, resulta un instrumento epistémico infinitamente superior al acuerdo entre fiscal e imputado que precede a la condena en el juicio abreviado y simplificado previo reconocimiento de responsabilidad. Ninguno de los déficits que se pasan a exponer son predicables del proceso civil, y es eso precisamente la causa de que la sentencia penal negociada no sea traspasable al juicio civil por la vía de reconocerle el mérito de cosa juzgada.

Como adelantaba, tanto el juicio abreviado como el simplificado previa admisión de responsabilidad no permiten alcanzar la verdad en el proceso, por una serie de razones. A continuación las he sistematizado, en lo que he denominado (1) el déficit de incertidumbre, (2) el déficit adversarial y (3) el déficit de juicio jurisdiccional.

\section{Déficit de incertidumbre}

Puede decirse, siguiendo la idea de Luhmann ${ }^{72}$, que lo que legitima al juicio jurisdiccional como forma de búsqueda del conocimiento -de la ver-

\footnotetext{
71 Montero (2011), p. 50, señala que "relativizada la pretensión de obtener la verdad, es decir, la verdad objetiva de los hechos, aparece la función de lograr otra realidad, si bien subjetiva, la convicción del juez".

72 Luhmann (2013).
} 
dad-es precisamente que las partes ignoran ex ante cuál será el resultado del proceso. Es esa incertidumbre con que las partes se enfrentan al proceso, lo que le otorga aceptación social y legitimidad como forma idónea de resolver conflictos y de llegar a conocer la realidad. Por lo mismo, un proceso en que una o ambas partes tengan la certeza de cómo terminará, será un fraude, un arreglo entre partes ${ }^{73}$, "una comedia en que los papeles están escritos de antemano" 74 , pero no un procedimiento jurisdiccional. Esto que parece tan obvio para cualquiera, colisiona con estos procesos penales, en que se dicta un fallo que ambas partes saben de antemano su contenido. Esta sola circunstancia, más allá de los problemas anotados más arriba, parece restarles legitimidad como vía de establecimiento de la verdad. Y si no es posible determinar la verdad en sede penal, no será posible traspasarla ni hacerla valer en el proceso civil.

Asimismo, en estos procesos penales se elimina también la incertidumbre que el juez debe tener sobre el resultado del juicio, que en el caso del proceso penal, cobra fuerza como garantía fundamental irrenunciable bajo la forma del in dubio pro reo, o que no puede ser condenado más allá de toda duda razonable. Como acota Nieva, "la duda recae al menos sobre el juez. En el proceso penal, la duda se ha percibido desde muy antiguo como uno de sus elementos más sustanciales" ${ }^{\prime 75}$. Al respecto, Díaz dice que en el juicio abreviado se estaría "asegurando la máxima certidumbre o seguridad posible de las decisiones condenatorias" $^{\prime 76}$.

\section{Déficit adversarial}

La confrontación de dos versiones sobre un hecho ha sido, desde antiguo, estimada como la forma idónea de llegar a fijar la verdad. Como acota Foucault, a propósito precisamente del proceso penal, el adversarial ya era el estándar en la Grecia clásica, y es también la idea matriz de la obra de John Stuart Milli7,

\footnotetext{
73 Dewey (2008), p. 195.

74 Calamandrei (1945), p. 266.

75 Nieva (2013), 13.

76 DíAz (2005), p. 257.

77 Mill (2009), p. 102: "en todo asunto en que es posible la diferencia de opiniones, la verdad depende de la conservación de un equilibrio entre dos sistemas de razones contradictorias. Hasta en la filosofía natural hay siempre alguna otra posible explicación de los mismos hechos (...) cuando nos volvemos a asuntos infinitamente más complicados, como los morales, religiosos, políticos, las relaciones sociales o los negocios de la vida, tres cuartas partes de los argumentos en pro de una determinada opinión consisten en destruir las apariencias que favorecen las opiniones distintas a ella (...) quien sólo conozca un aspecto de la cuestión no conoce gran cosa de ella".
} 
incluso recogida por el propio Nietzsche ${ }^{78}$. Más que el solo enfrentamiento de dos versiones contrapuestas y antagónicas acerca de un mismo hecho, el juez lo que hace es tomar fragmentos de la realidad traída por las partes a través de sus probanzas, y construir una verdad propia. Asimismo, las discrepancias de las partes suelen estar no en los antecedentes fácticos mismos, sino en las calificaciones jurídicas, ponderaciones o adjudicaciones que de ellos se hacen, dado el carácter comunicativo de ésta. Aunque teóricamente sólo el Ministerio Público debe acreditar los hechos de su acusación, pudiendo la defensa desplegar una actitud pasiva, la ley procesal dota de herramientas eficaces al imputado para proveerse de una defensa material y técnica que le permita contrastar el caso del fiscal con su propia teoría de inocencia o atenuación de responsabilidad. El punto es que nada de ello ocurre en el proceso abreviado ni en el simplificado en que se admite responsabilidad por el imputado. En el juicio abreviado no llegan ante el juez de garantía dos versiones contrapuestas, sino una "verdad previamente negociada" entre el fiscal y la defensa. A pesar de que la etiqueta "inquisitivo" suele ser puesta por la doctrina garantista ${ }^{79}$, creo que es más correcto decir que se trata de un déficit "adversarial", y no acusatorio, en que se entiende al Ministerio Público como una parte en el proceso, que enfrenta su versión de los hechos con la de la defensa ${ }^{80}$. Para Armenta, el abreviado sería "el abandono de la determinación de la verdad, sustituido por cualquier objeto de acuerdo", en que se afecta, además, la publicidad y transparencia del proceso como contribuyentes a la prevención del delito y la estabilidad social, afectándose en definitiva el de-

\footnotetext{
${ }^{78}$ Foucault (2000), p. 8-10. Citando a Nieztsche, señala que "el conocimiento es simplemente el resultado del juego, el enfrentamiento, la confluencia, la lucha y el compromiso entre los instintos. Es precisamente debido a ello que los instintos chocan entre sí, se baten y llegan finalmente al término de sus batallas, que hay un compromiso y algo se produce. Este algo es el conocimiento". También citando a Nietzsche, hace una referencia que parece muy propia del debate judicial, aunque no lo es: "hemos de decir que esas tres pasiones o impulsos -reír, detestar y deplorar- tienen en común el ser una manera no de aproximarse al objeto, de identificarse con él, sino de conservar el objeto a distancia, de diferenciarse o de romper con él, de protegerse de él por la risa, desvalorizarlo por la deploración, alejarlo y finalmente destruirlo por el odio".

79 Montañez (2013), pp. 68-70.

${ }^{80}$ ARMENTA (2012), p. 33, quien identifica como nota característica del sistema adversaria (o "adversativo") el "aceptar como verdad plausible el resultado de la confrontación entre la aportación y práctica de la prueba por las partes". También se explaya, pp. 34-36, entre la confusión entre el sistema acusatorio y el adversarial. La nota característica del primero sería "el ejercicio de la acción por un sujeto diferente del juez (Nemo iudex sine actore, Wo kein Klage, da kein Richter)". En la misma obra, p. 44: "la búsqueda de la verdad (...) se configura en el modelo adversativo como el resultado de las manifestaciones contrapuestas de las partes". Para esta autora, p. 52, constituye un error "argumentar que el 'plea bargaining' es elemento sustancial y altamente valorado en el sistema adversarial", por el solo hecho que su existencia presupone la confrontación de las partes en el proceso.
} 
recho a la tutela judicial efectiva, al negarse el proceso como único vehículo para garantizarla, resultando así en una verdadera denegación de justicia ${ }^{81}$. Como acota Alberto Bovino, "el método que se considera más idóneo para aproximarse a la verdad, y además, para no afectar derechos individuales en el proceso de averiguación es, sin duda alguna, el modelo falsacionista del garantismo desarrollado por Ferrajoli. En este marco, se procura que la verdad surja de la "máxima exposición de la hipótesis acusatoria a la refutación de la defensa", de modo que no sea atendible ninguna prueba sin que se hayan activado, infructuosamente todas las posibles refutaciones o contrapruebas (...) el juicio abreviado por su carácter no contradictorio, no puede ser un mecanismo idóneo para demostrar la verdad de la imputación con un grado mínimo de confiabilidad"82.

Así, la aceptación de los hechos por parte del imputado no es garantía de que la verdad haya sido descubierta o revelada. Como señala Taruffo: "Si el enunciado alegado es falso, la no oposición no lo convierte en verdadero; si el enunciado alegado es verdadero, la no oposición no lo convierte en verdadero, porque ya lo es; si el enunciado alegado es verdadero (...) resulta por lo tanto claro que en lo que respecta a la verdad o a la falsedad del enunciado que ha sido objeto de la alegación, la oposición o la no oposición de él son absolutamente irrelevantes (...) se excluye que el acuerdo de dos o más sujetos pueda cambiar el estatus epistémico de un enunciado, en particular determinándole la verdad"83. El concepto de la "justicia de la decisión", acuñado por este autor, precisamente establece una "necesidad de la verdad", que el juez debe comprobar, incluso completando o excediendo las probanzas que las partes rindieron y, por lo mismo, no siendo suficiente la mera disposición de las partes en el proceso ${ }^{84}$. O como acota Foucault, el producto consensual de este tipo de acuerdos es realmente una solución generada y acordada por las partes y, por lo mismo, un realidad verdaderamente creada por ellos ${ }^{85}$. Nicolás Rodríguez apunta que en el sistema norteamericano "es probable que el juez

\footnotetext{
81 Armenta (2013), pp. 252-254. Armenta (2012), pp. 92-93: "la verdad [en el sistema adversarial], más que conformar un concepto objetivo, se deja a la mejor gestión de los medios de prueba (...) Así se plasma en una frase conocida: 'The trial judge's role is to determinate where the truth lies between the competing versions of the parties' (...) desde esta perspectiva angloamericana, el sistema adversativo se concibe como el más eficaz al entender que la lucha equitativa de las dos partes hace que la verdad aflore con mayor probabilidad que a partir de la iniciativa judicial".

${ }^{82}$ Bovino (2005), pp. 85-86.

${ }^{83}$ TARufFo (2012), pp. 196-197.

84 TARUFFO (2006).

85 Foucault (2000), p. 31.
} 
nunca llegue a conocer la realidad de los hechos", ya que los acuerdos se adoptan con la poca evidencia que ha logrado reunir el fiscal, en una etapa muy temprana del proceso $^{86}$.

\section{Déficit de juicio jurisdiccional}

Finalmente, puede decirse que el juicio abreviado no es ni juicio ni tampoco es abreviado. Es un no-juicio, o sea, no es un acto en que exista un juicio jurisdiccional propiamente tal sobre el fondo del asunto. Aunque el resultado del proceso sea incierto, y aunque efectivamente exista un sistema adversarial, si no existe juicio jurisdiccional, no podrá hablarse de que se obtuvo la verdad en el caso.

Esto, sin perjuicio de que el tribunal de garantía sí evalúa razonadamente que se cumpla con ciertas formalidades. El caso chileno es particular, ya que a diferencia del plea bargaining estadounidense, el juez está llamado a calificar la "suficiencia" de los antecedentes contenidos en la carpeta investigativa, como, asimismo, a calificar si el consentimiento del imputado ha sido libre y voluntario. Pero no existe, por ejemplo, ninguna obligación del juez de advertir al imputado acerca de las consecuencias civiles de la admisión de hechos o de responsabilidad. Respecto del primer requisito, el actual art. 410 CPP proviene de un proyecto que en la historia de la ley consignaba la prohibición de que el imputado fuere juzgado sobre la base únicamente de partes policiales. De cualquier forma, esta calificación que hace el tribunal de garantía de los antecedentes de la investigación, en caso alguno puede estimarse como un sucedáneo de una inducción de los hechos, ni como una deducción de las consecuencias jurídicas. En realidad, quien ha hecho ambas tareas -inducción y deducciónparece ser el propio fiscal, quien incluso puede modificar su acusación (art. 407 inc. $3^{\circ} \mathrm{CPP}$ en el caso del abreviado; art. 395 en caso del simplificado) para "hacer calzar" sus pretensiones con los requerimientos legales para lograr un acuerdo ${ }^{87}$. Asimismo, se discute si es posible que el juez de garantía tenga la prerrogativa de absolver al imputado que ha aceptado el juicio abreviado, la que de cualquier forma parece muy acotada a ciertos casos excepcionales ${ }^{88}$. En

\footnotetext{
${ }^{86}$ RodríGuez (1995), p. 102.

87 Un ejemplo de prácticas abusivas del Ministerio Público, que vulnerarían los principios de legalidad e igualdad ante la ley, se encuentra en el trabajo de Dé Río (2008), pp. 167-169.

${ }^{88}$ SALAS (2015), pp. 267-271, niega que el tribunal de garantía pueda absolver por existir "duda razonable" respecto de los hechos constitutivos de delito y la participación del imputado en ellos. A su juicio -y parece razonable que así sea-, la calificación de suficiencia que ordena el art. 410 CPP es el único y último test que hará el juez respecto del fondo del asunto, evitando así que el acuerdo entre fiscal e imputado, que primeramente fue declarado suficiente, finalmente sea objeto de un segundo control
} 
el voto de minoría del Ministro Mario Fernández de la sentencia del caso Jesús Manzur Saca (2011), se señaló que "si el tribunal acepta el juicio abreviado es porque acepta la pena propuesta, o sea, es el fiscal el que la ha impuesto, ejerciendo, por lo tanto, funciones jurisdiccionales".

En estos procesos falta, precisamente, un juicio en que un tribunal pondere los antecedentes probatorios que ante él se han traído, para emitir una decisión, juicio que es la única vía idónea para la adquisición del conocimiento acerca de la verdad. Los acuerdos a los que el imputado y fiscal puedan llegar no establecen la verdad de los hechos, sino que, como en toda negociación, las partes están dispuestas a tolerar ciertas concesiones a su contraparte (y de paso, a la verdad) para arribar a un acuerdo que se estima como conveniente. En el sentido de lo que decía al comienzo, Taruffo acota con razón que el contradictorio en el proceso es condición necesaria, pero no suficiente, para que exista una solución justa en el proceso. Si el proceso consistiera en la mera contrastación de las posiciones de las partes, para finalmente suscribir un acuerdo, sin intervención del juez, es muy posible que jamás se llegaría a establecer una verdad de lo que realmente ocurrió ${ }^{89}$.

de fondo, en que el juez deba convencerse más allá de toda duda razonable. A la misma conclusión arriba FALCONE (2005), p. 371, quien decía que otorgar esa prerrogativa al juez sería vaciar de contenido la conformidad del imputado y la institución misma del juicio abreviado. De todas formas, no hay que olvidar que en el juicio abreviado el imputado sólo reconoce los hechos, debiendo el Tribunal aplicar soberanamente el derecho, pudiendo calificarlos de forma distinta que lo originalmente solicitado, previo debate entre las partes. En este sentido, RieGo (2005), p. 460, quien admite, con razón, que el juez de garantía podría igualmente absolver por razones de culpabilidad disminuida del sujeto, o también la prescripción de la acción penal. La imposibilidad de absolver por existir una duda razonable parece refrendado por el hecho de que durante el trámite legislativo nunca vio la luz la indicación de la Cámara de Diputados, en el sentido que "se faculta al juez para absolver en el caso de que, a pesar del reconocimiento de hechos realizado por el acusado, éstos no sean constitutivos de delito o el conjunto de los antecedentes de la instrucción lo llevaren a adoptar esa decisión" (en Maturana (2009), p. 211). Por su parte, Horvitz (2004b), p. 531, sostiene que, por aplicación del art. 412 CPP, el juez goza de una amplia prerrogativa para absolver, debiendo aplicar el estándar de "más allá de toda duda razonable". También en Maturana (2009), p. 250, se consigna la opinión del primer Fiscal Nacional, Sr. Guillermo Piedrabuena, en el sentido de que "el problema que observo es en relación a la posibilidad que debe tener siempre el juez para dictar sentencia absolutoria y no necesariamente condenatoria (...) el art. 473 del proyecto no excluye la posibilidad de absolución y ella será siempre posible si concurre alguna causal de extinción de la responsabilidad penal". Nieva (2012), pp. 218-219, dice que un reconocimiento de responsabilidad por parte del imputado sería vulnerador de su derecho a no autoincriminarse, y que de cualquier forma ese reconocimiento no sería vinculante para el juez. Lo que correspondería es que el imputado asuma la pena solicitada, y no los hechos.

89 TARUfFO (2012), pp. 187-188: "las partes no tienen a priori algún interés en la determinación de la verdad. Antes, bien, se ha observado que los abogados de las partes hacen recurso de su habilidad profesional precisamente para evitar que se descubra la verdad, y no es enteramente cierto que el contradictorio entre las partes conduzca hacia la verdad". En el mismo sentido, TARUFFO (2010), pp. 57 y siguientes. Calamandrei (1945), p. 263: "si excluimos al juez, en quien debería personificarse concre- 
En la doctrina española se discutió si el efecto de cosa juzgada lo producía la sentencia misma o bien el proceso en que ella se pronunciaba, debate que nos es útil respecto de la sentencia del juicio abreviado y de la admisión de responsabilidad en el simplificado, en que no existe propiamente un juicio jurisdiccional, un proceso. Pablo Grande, recogiendo la idea de De la Oliva Santos, señalaba "resulta indiferente decir que la cosa juzgada material es un efecto de la sentencia o que es un efecto del proceso, por cuanto es impensable una sentencia sin proceso ${ }^{\prime \prime 90}$. Aunque no comparto la idea de que el juicio abreviado no produzca cosa juzgada respecto de futuros juicios penales, como apuntaba también Jordi Nieva, la discusión es interesante para ilustrar el déficit de juicio jurisdiccional de este procedimiento.

\section{6. la admisión de hechos y de responsabilidad como confesión extrajudicial en el proceso civil}

\section{En el juicio civil seguido en contra del propio imputado}

De lo dicho hasta aquí es posible concluir que la sentencia pronunciada en estos procedimientos no corresponde al establecimiento de la verdad, ni siquiera de aquella acotada parcela de realidad que corresponde al objeto del juicio penal, consistente en los enunciados de la acusación fiscal, referidas a las conductas descritas en el tipo penal. Como se ha señalado, estos procesos adolecen de un manifiesto déficit de "adversariedad", que hace inviable la confrontación de la acusación y defensa y, por lo mismo, vulnera las garantías fundamentales del imputado en la obtención de la condena por parte del Ministerio Público.

Sin embargo, parece evidente que la admisión de los hechos y de responsabilidad -no la condena- algún valor deben tener en el proceso que se siga para perseguir la responsabilidad civil que nace de los hechos dañosos que subyacen al ilícito penal. Si dicha admisión legitima que un tribunal de garantía imponga una pena, aun con todos los cuestionamientos que la doctrina ha denunciado, existiría una incongruencia si dicha admisión fuera inexistente para el juicio civil posterior.

Lo que se propone es que, aun cuando la "verdad negociada" no pueda ser validada como cosa juzgada en el proceso civil, es imposible desconocer que el imputado admitió los hechos o la responsabilidad en que se fundó, legalmente, dicha condena. Por lo tanto, para el proceso civil existirá una confesión extrajudicial, en los términos del art. 398 CPC. Dispone esta norma que "la confesión

tamente ese superior interés de la justicia que es propio del Estado, todos los demás sujetos persiguen en el proceso finalidades más limitadas y burdamente egoístas".

${ }^{90}$ Grande (2008), p. 37. 
extrajudicial es sólo base de presunción judicial, y no se tomará en cuenta, si es puramente verbal, sino en los casos en que sería admisible la prueba de testigos. La confesión extrajudicial que se haya prestado a presencia de la parte que la invoca, o ante el juez incompetente, pero que ejerza jurisdicción, se estimará siempre como presunción grave para acreditar los hechos confesados. La misma regla se aplicará a la confesión prestada en otro juicio diverso; pero si éste se ha seguido entre las mismas partes que actualmente litigan, podrá dársele el mérito de prueba completa, habiendo motivos poderosos para estimarlo así"

De la norma recién transcrita, parece claro que el reconocimiento de hechos o de responsabilidad en sede penal corresponde a la hipótesis de "la confesión prestada en otro juicio diverso", por lo que no será necesario entrar en disquisiciones acerca de qué se entiende por confesión extrajudicial, más allá de su sentido natural y obvio, que en este caso, corresponde a "una declaración que hace el que es parte en un juicio sobre la verdad de un hecho contrario a su interés y favorable al adversario" ${ }^{\prime 92}$, definición que corresponde al Código Civil italiano, según consigna Alessandri ${ }^{93}$. La norma parece concebida en términos lo suficientemente amplios, y por lo mismo no debiera restringirse el concepto de "confesión extrajudicial" sólo a las prestadas en otro proceso civil, sin perjuicio de que en el CPP no existe la confesión propiamente tal como medio de prueba, como sí sucede en el Derecho comparado. El inciso primero alude a la confesión prestada en cualquier documento o soporte fuera del proceso, no sólo en un juicio diverso. Por lo mismo, no hay razón para restringir el alcance del inciso segundo, teniendo en cuenta además que éste alude en términos expresos a las declaraciones prestadas incluso ante un juez incompetente. Así también lo ha entendido jurisprudencia reciente del caso Roblin con Esquivel (2011), que acogió una demanda civil de cobro de pesos, apoyada en los registros de audio de una audiencia ante un juez de garantía, en que "se pretendió llegar a un acuerdo reparatorio" (al que nunca se arribó) en un proceso seguido por la misma demandante contra la demandada por el delito de estafa. Para la Corte, fue suficiente ese reconocimiento de la deuda en audiencia para aplicar la norma

\footnotetext{
${ }^{91}$ Lazo (1918), pp. 356-358. En las actas de la discusión de la Comisión Redactora del CPC se consignó que "los señores Gandarillas y Zegers, los cuales creen que, confesado un hecho con la especificación necesaria para estimarlo legalmente verdadero en un juicio, debe apreciársele de igual modo en todos los demás. Sería autorizar una inmoralidad permitir que el litigante pueda alterar en cada pleito sus declaraciones según el interés del momento". En contra se pronunció el comisionado señor Lira, quien señaló "la confesión como los demás actos del juicio es relativa al pleito en que incide, es prestada en consideración a él, no puede ser ampliada con circunstancias que la modificarían por lo que respecta a otros negocios pero que no son pertinentes en aquel de que se trata".

92 Paillás (1979), p. 103.

93 Alessandri y otros (1998), p. 493.
} 
del art. 398 CPC, descartando expresamente que se aplicara la exclusión del art. 335 CPP, la que se estimó correctamente sólo aplicable al juicio oral penal. En la sentencia del caso Fisco de Chile con Carrillo (2011), se acogió también una demanda civil de cobro de pesos, considerando que "en sede penal el ahora demandado ha aceptado expresamente los hechos de la acusación en los términos que establece el artículo 406 del Código Procesal Penal, lo que de conformidad a lo dispuesto en el artículo 398 inciso segundo parte final del Código de Procedimiento Civil, se estimará como una confesión extrajudicial prestada en juicio diverso y con valor de plena prueba". Sin embargo, este criterio no ha sido unánime, y la Corte Suprema en un caso reciente ha reconocido el valor de cosa juzgada en el juicio civil de la sentencia condenatoria pronunciada en el juicio abreviado, como en Consejo de Defensa del Estado con Geyte (2013).

El legislador procesal civil sometió a la confesión en general, y a la confesión extrajudicial en particular, al sistema de la prueba legal o tasada, o también Ilamada apriorística ${ }^{94}$, reservada sólo para algunos medios de pruebas en el proceso civil ${ }^{95}$, Ilegando a dotarla del valor de plena prueba en ciertos casos (art. 399 CPC en referencia al art. 1713 del Código Civil, cuando se trata de hechos propios). A pesar de la nomenclatura medieval ${ }^{96}$ que emplea el art. 398 CPC ("prueba completa"), debiera entenderse que el juez debe apreciarla también como plena prueba, o sea, como un elemento que provoca la certeza del juez ${ }^{97}$. Sin embargo, y siendo estrictos en la interpretación de la norma del art. 398, el valor de plena prueba sólo podría darse en estos casos, si en el juicio penal existió al menos una querella en contra del imputado y luego demandado, en orden a dar cumplimiento al requisito de que se haya tratado de un juicio "entre las mismas partes que actualmente litigan". De lo contrario, se la considerará "sólo" una presunción grave para acreditar los hechos confesados.

La admisión de los hechos en el juicio abreviado, o de responsabilidad en el simplificado, acarreará, normalmente, la condena del imputado. Sin embargo, en el juicio civil no debiera ocurrir lo mismo, por dos razones. En primer lugar, porque como apuntaban Enrique Barros y Hernán Corral más arriba, el reconocimiento sólo lo fue respecto del hecho ilícito generador del daño. Por lo tanto, restará al actor civil acreditar adicionalmente -al menos- la ocurrencia

\footnotetext{
94 Montero Aroca (2011), pp. 596-598.

95 PallLás (1979), p. 32.

96 Paillás (1979), p. 3; Couture (2014), pp. 220-221.

97 Maier (1989), p. 569. Romero Coloma (2009), pp. $93-94$ y 113, señala que "el motivo de que la Ley le atribuya a la confesión la fuerza de plenitud probatoria obedece al criterio de normalidad, en el sentido de que ninguna persona de buen juicio es capaz de hacer declaraciones contrarias a su interés, si no son conformes a la verdad. Pero esta teoría es discutible".
} 
de un daño patrimonial y de una relación causal directa y necesaria entre el ilícito y el daño, de acuerdo a las normas de los artículos 2314 y siguientes del Código Civil. Lo anterior, sin perjuicio de otras complejidades que puede tener el traspaso de la realidad penal determinada en la sentencia (consistente en la ocurrencia de hechos que corresponden a un tipo penal) a un juicio civil en que no siempre serán coincidentes la culpa civil con la culpa penal, o puede requerirse un dolo civil distinto al establecido previamente en sede penal ${ }^{98}$. La segunda razón es la aplicación de la norma del art. 428 CPC, cuando existen pruebas contradictorias con la confesión prestada en el juicio abreviado o simplificado, sobre todo, si todas ellas tienen el mismo valor probatorio.

También podrían existir importantes escollos para el juez civil en apreciar la confesión del imputado en el juicio abreviado o simplificado, si finalmente queda en evidencia, por otras pruebas, que su admisión de los hechos era falsa o sólo la hizo por razones estratégicas o de conveniencia. El tema en todo caso, no es pacífico en la doctrina ni en la jurisprudencia, como lo consigna Anabalón ${ }^{99}$. No hay que perder de vista que si bien puede existir un deber moral del imputado de decir verdad, éste goza de la garantía constitucional de no autoincriminarse, y en todo caso, no existe sanción alguna en caso de que haya mentido en el proceso penal -aun en la admisión de los hechos o de responsabilidad en el juicio penal ${ }^{100}$. De todas formas, no existe un deber genérico de decir verdad respecto de los particulares, salvo en contextos legalmente acotados ${ }^{101}$, por lo que en teoría todas las confesiones, judiciales o extrajudiciales, podrían ser

98 Ried (2015), pp. 18-20.

99 AnABalón (1963), pp. 434-435: "puesto que la confesión en juicio constituye según la ley -como se ha visto- plena prueba contra el confesante y, por ende, releva de toda prueba al contendor con relación al hecho confesado, es inconcuso que ninguna otra producida por el mismo confesante logrará desvirtuarla (...). De ahí también que la jurisprudencia de nuestros tribunales no haya vacilado en establecer hasta que "la confesión judicial prima sobre lo expuesto por el confesante en escritura pública anterior" (...). A pesar de la claridad y evidencia de las conclusiones anteriores, ha habido algunos fallos que han establecido la doctrina -equivocada por cierto- de que, frente a la contradicción existente entre la confesión del litigante con la prueba testimonial y otra rendida por él en la causa, el tribunal está facultado para dar mayor valor a cualquiera de estas últimas pruebas que a la primera, ya que con ello no hace más que asilarse en el artículo 428, concerniente al examen comparativo de las pruebas". En contra, Romero Coloma (2009), p. 113, quien cita jurisprudencia del Tribunal Supremo español.

100 Romero Coloma (2009), p. 32. En el ordenamiento español (art. 387 de la Ley de Enjuiciamiento Criminal) el juez de instrucción exhorta al imputado a decir verdad, aunque no le toma juramento. En el CPP chileno, la norma que regula la declaración del imputado en el juicio oral (art. 326) simplemente señala que el juez "permitirá que manifieste libremente lo que creyere conveniente respecto de la o de las acusaciones formuladas". En la declaración ante el fiscal, el art. 194 CPP señala en términos parecidos que el imputado "podrá declarar cuanto tuviere por conveniente sobre el hecho que se le atribuyere"; al respecto, HORvitz (2004a), pp. 494-497.

101 SILVA (2011), pp. 555-569. 
mendaces, con lo cual la norma procesal civil que consagra la confesión como medio de prueba sería inidónea para determinar la verdad ${ }^{102}$. Pero lo que la norma hace es precisamente asumir que lo confesado es verdadero y darle un valor preponderante como prueba. Y salvo que existan buenas razones para estimar que el reconocimiento de hechos o responsabilidad efectuado por el imputado en sede penal fue fingido, y ello pueda ser acreditado, ese acto procesal debe ser tenido como una confesión en el juicio civil.

De lo dicho hasta ahora, podría ciertamente objetarse que el imputado, al reconocer los hechos en sede penal, no conocía que dicha aceptación le acarrearía además consecuencias civiles, ya que efectivamente la norma procesal penal no establece deber alguno al juez de garantía de prevenir al imputado en ese sentido. Pero esta objeción no me parece atendible. Primero, porque por regla general ninguna persona que confiesa en juicio está plenamente consciente de las consecuencias que reconocer un hecho desfavorable le traerá, principalmente porque (como suele suceder en los juicios de responsabilidad civil ex delicto) el proceso civil sólo se inicia con posterioridad a la condena penal. En rigor, al legislador le es indiferente si el confesante estaba consciente de los riesgos o consecuencias de su reconocimiento de hechos desfavorables, sea que se haga en un juicio civil o penal diverso. Además, como se expuso, la norma del art. 398 del CPC ha venido siendo aplicada por nuestros tribunales respecto de los juicios abreviado y simplificado en que existió reconocimiento de responsabilidad.

\section{En el juicio civil seguido contra un tercero civilmente responsable}

Por otra parte, en los juicios indemnizatorios seguidos en contra de terceros civilmente responsables, la confesión penal prestada por el imputado no tendrá el valor de plena prueba, por aplicación del art. 398 CPC ya citado, en razón que dicha admisión de hecho no se prestó en un juicio diverso entre las mismas partes, sino entre personas distintas. Por lo tanto, respecto del tercero civilmente responsable que no participó en el juicio penal, la sentencia condenatoria pronunciada en un juicio abreviado o simplificado en que admitió responsabilidad parece no ser válida, ya no como cosa juzgada, y ni siquiera en lo tocante a las admisiones de hechos efectuadas por el imputado. Por lo mismo, dicha sentencia tendrá el valor de un simple documento, entendida como un "hecho jurídico" que en este caso produce efectos muy limitados ${ }^{103}$; en este entendido,

102 Sobre la problemática jurídica de las confesiones falsas, en muchos casos por enfermedades psiquiátricas, vid. ROMERO COLOMA (2009), pp. 115-124.

103 Romero (2012), pp. 262-264. 
el actor civil deberá acreditar sus pretensiones como si la sentencia fuera sólo un documento más, ilustrativo por cierto, pero que no goza del efecto de cosa juzgada, ni vale como confesión extrajudicial.

Sin perjuicio de lo anterior, se presenta aquí un problema adicional, que es la injusticia que alguna doctrina ha detectado en que se valide una condena respecto de un tercero que no pudo participar en el juicio penal, por las razones ya explicitadas más arriba, referidas al diseño de la Reforma Procesal Penal. El problema se enmarca en un tema que ha sido tratado profusamente en la doctrina procesal, aunque las soluciones propuestas no siempre son satisfactorias. Siguiendo la tesis de Liebman ${ }^{104}$, se suele distinguir entre el efecto de cosa juzgada (entendido como inmutabilidad del fallo), que sólo sería inter partes, y los efectos reflejos propios de cada sentencia como hecho jurídico (que podrían ser constitutivos, declarativos o de condena). Estos últimos serían -en el caso del art. 178 CPC- erga omnes y ultra partes, precisamente para evitar la producción de fallos contradictorios. Como han notado algunos autores, esta norma encierra una vulneración de las garantías fundamentales del tercero que no pudo intervenir en el juicio penal, en lo referido al debido proceso (ausencia de contradictorio, en este caso), que tiene su causa precisamente en que la acción civil se debe intentar fuera del juicio penal, en la mayoría de los $\operatorname{casos}^{105}$. El asunto es particularmente evidente si se tiene en cuenta que ni el actor civil ni el tercero civilmente responsable nunca podrán intervenir en el juicio abreviado ni en el simplificado. En este sentido, resulta interesante la propuesta de Nieva para Ilenar la misma laguna legal que se genera en el Derecho español, de que "el tercero perjudicado por una resolución judicial pueda solicitar su revisión por el mismo juez que la dictó, teniendo en cuenta que el anterior proceso fue sustanciado sin él"106, como lo consagra el Código procesal civil francés e italiano ${ }^{107}$. En todo caso, el problema parece tener solución en el Proyecto de Código Procesal Civil chileno, que dispone en su artículo 219 que "los efectos vinculantes de la sentencia penal condenatoria en el proceso civil no tendrán lugar si el demandado en el juicio civil no ha participado como interviniente en el proceso penal".

El problema fue planteado recientemente a propósito del caso Domínguez con Donoso y otro (2015), en que un tribunal civil de primera instancia condenó

\footnotetext{
104 Liebman (1946), p. 38; Rosende (2001), pp. 489-507.

105 Rojas (2013), p. 15; Carocca (2006), p. 35; Grande (2008), pp. 126-128; Romero (2015), p. 467; COUture (2014), pp. 209-210.

106 Nieva (2006), pp. 211-214.

107 Allorio (2014), p. 79.
} 
a un colegio al pago de una indemnización de perjuicios a favor de una alumna menor de edad y su familia, abusada sexualmente en el establecimiento por un chofer del transporte escolar. Este último había reconocido los hechos en un juicio abreviado, resultando penalmente condenado. La condena civil se hizo extensiva no sólo al chofer sino también al colegio, que evidentemente no había podido intervenir en el juicio penal, solicitándose por el actor la aplicación del art. 24 del Código Penal. Aunque el juzgado civil no fue explícito en la norma que aplicó para condenar al colegio, sí dio por indubitadamente establecidos los hechos reconocidos en el juicio abreviado, lo que motivó la solicitud de inaplicación por inconstitucionalidad de esa norma ante el Tribunal Constitucional en la causa Eugenio Domínguez Delpiano y otros (2015), por las razones más arriba apuntadas. Este último órgano rechazó la acción constitucional, atendido, entre otras razones, a que se trataba de un asunto de "mera legalidad" que estaba fuera de su competencia, y a que -precisamente- no se había solicitado la inaplicación de los artículos 178 y 180 CPC (considerandos $22^{\circ}$ y $23^{\circ}$ ).

\section{El problema de los acuerdos parciales en procesos con pluralidad de imputados}

\section{En el proceso penal}

El problema de la confesión del imputado como medio de prueba ha sido objeto de numerosas y antiguas discusiones en la doctrina y, en general, suele mirarse con mucho recelo el valor probatorio que tiene en el proceso ${ }^{108}$. En Chile, en el proceso penal vigente con anterioridad a la reforma, y dado su carácter inquisitivo, parecía ser que la función primordial del juez era obtener la confesión del procesado, como ratificación final y total de su investigación sumaria. Es en ese contexto en que los "careos"109 eran un medio de prueba fundamental, para contrastar las declaraciones de imputados que mentían con las de otros imputados o testigos. En el derecho procesal penal español el valor procesal de la declaración del imputado sigue siendo un tema actual y discutido. En Chile, a partir de la Reforma Procesal Penal, la confesión del imputado perdió toda relevancia. Como anota Roxin, "el imputado no es medio de prueba en sentido técnico, como lo es el testigo"110, y "tampoco un coimputado puede ser interrogado como testigo sobre la contribución al hecho de otro imputado"111.

\footnotetext{
108 Ragués I Valles (1999), pp. 233-237; pp. 420-423.

109 Arts. 351 y ss. Código de Procedimiento Penal.

110 Roxin (2001), p. 208.

111 Roxin (2001), p. 220.
} 
Ya desde la investigación, el imputado tiene derecho irrenunciable a guardar silencio (art. 93 g) CPP; art. 19 № 7 f de la Constitución Política de la República), el que puede mantener durante todo el proceso si así lo estima conveniente para su defensa. Durante el juicio oral el imputado no puede ser obligado a declarar, aun cuando ya hubiese prestado declaración ante el fiscal instructor de la investigación (art. 326 CPP, que contempla una mera "posibilidad" pero no la obligación de declarar). Y aun declarando, no puede ser condenado con el único mérito de esa declaración autoinculpatoria. Todas estas prerrogativas del imputado han tenido una consecuencia bien evidente en la litigación penal, y es que ninguno de los intervinientes cuenta con la declaración o la confesión del imputado como un medio de prueba "seguro" y menos "ganador" en el proceso. El Ministerio Público se ve obligado a diseñar estrategias probatorias que no cuentan con que el imputado se autoincrimine, debiendo ofrecer y rendir pruebas distintas para acreditar su imputación.

Sin embargo, la situación puede ser distinta si se trata de un juicio contra una pluralidad de acusados, y éstos ejercen su derecho a declarar; o bien, en lo que me interesa en este trabajo, cuando algunos de ellos aceptan los hechos en juicio abreviado, y otros deciden ser juzgados en un juicio oral posterior.

La admisión de los hechos que hace el imputado puede ser gravitante para la situación procesal de otros coimputados por el mismo hecho o hechos conexos, por dos razones. Primero, porque podría utilizarse como prueba en el juicio oral la sentencia condenatoria en juicio abreviado de los otros imputados, haciendo una interpretación restrictiva del art. 335 CPP. Segundo, porque aun no admitiéndose como prueba ese antecedente, podría suceder que los términos negociados con los imputados que accedieron al juicio abreviado consistían precisamente en su colaboración como testigos en contra de otro de los imputados que irá a juicio oral. Se da entonces la paradoja que en el juicio oral la confesión del imputado no es obligatoria ni tiene mayor valor procesal; en cambio, respecto de los coimputados, la admisión de los hechos respecto de uno puede incriminar a los que no acepten el arreglo con el persecutor. Aún más: podría suceder que uno de los coimputados acepte los hechos y sea condenado; y el resto de los imputados ejerza su derecho de ir a juicio oral, resultando posteriormente absueltos, lo que puede dar origen a una situación paradójicamente arbitraria.

El art. 335 CPP dispone que "no se podrá invocar, dar lectura ni incorporar como medio de prueba al juicio oral ningún antecedente que dijere relación con la proposición, discusión, aceptación, procedencia, rechazo o revocación de una suspensión condicional del procedimiento, de un acuerdo reparatorio o de la tramitación de un procedimiento abreviado". La norma parece referirse, evidentemente, al acusado en juicio oral, precisamente porque como apunta Horvitz, "se desincentivaría la utilización de tales alternativas al juicio oral, 
pues el imputado sabría que su actitud previa podría eventualmente perjudicarlo en el juicio"112. ¿Es aplicable esta norma a los coimputados en la misma causa? ¿Es aplicable a los imputados en causas conexas? Del explícito tenor del art. 406 in fine, al parecer, la respuesta sería negativa: "la existencia de varios acusados o la atribución de varios delitos a un mismo acusado no impedirá la aplicación de las reglas del procedimiento abreviado a aquellos acusados o delitos respecto de los cuales concurrieren los presupuestos señalados en este artículo". Esta solución del legislador chileno contrasta, por ejemplo, con la del inciso final del art. 431 bis del Código Procesal Penal de la Nación (ley federal argentina), que dispone que "cuando hubiera varios imputados en la causa, el juicio abreviado sólo podrá aplicarse si todos ellos prestan su conformidad". Una norma similar contiene la Ley de Enjuiciamiento Criminal española respecto de varios imputados de un mismo hecho, evitando así la posibilidad de que se dicten fallos contradictorios y se genere "una auténtica indefensión al acusado disconforme que soportaría la celebración de un juicio presidido por un órgano de enjuiciamiento, inevitablemente, influido por las declaraciones de los acusados conformes"113. Respecto de la norma del art. 406 CPP, Horvitz da a entender que sí sería admisible que el coimputado condenado en juicio abreviado declare en contra de los restantes que decidieron ir a juicio oral ${ }^{114}$.

Este problema fue llevado a la justicia constitucional el año 2011 a propósito del caso Jesús Manzur Saca (2011) cuando el Ministerio Público acordó procedimientos abreviados con diez de un total de once imputados, decidiendo acusar formalmente a sólo uno de ellos ("el líder del grupo"), para acreditar su responsabilidad en un juicio oral. El imputado, a quien no se le ofreció el procedimiento abreviado, pidió al Tribunal Constitucional la declaración de inaplicabilidad del inciso final del artículo 406 CPP, alegando una discriminación arbitraria del Ministerio Público. Resulta interesante comprobar que la defensa de ese imputado se sintió -con razón- perjudicada con la celebración de otros diez procedimientos abreviados en que existían confesiones autoincriminatorias de todos los restantes imputados, y que lo implicaban directamente ya que se

\footnotetext{
112 Horvitz (2004b), p. 324.

113 LOZANO (2012), p. 351.

114 Horvitz (2004b), p. 526. A propósito del juicio oral propiamente tal, la misma autora señala, p. 316, que "tampoco pareciera inadmisible el ofrecimiento, esta vez en carácter de prueba testimonial, de la declaración de un coimputado condenado o absuelto por sentencia ejecutoriada", aunque más adelante se refiere a las objeciones doctrinales respecto de las declaraciones del coimputado que ha logrado beneficios por parte del Ministerio Público.
} 
trataba de los mismos hechos ${ }^{115}$, asumiendo así una suerte de efecto de cosa juzgada, que, insisto, estas sentencias no tienen. Como puede apreciarse, en situaciones donde existen varios imputados, la confesión de algunos de ellos en contra de los otros -si ésta ha sido aprobada por el tribunal de garantía en un procedimiento abreviado- sin duda genera una situación injusta para terceros ajenos a él. El requerimiento de inaplicabilidad fue rechazado, soslayando el impedimento del art. 335 CPP, fundamentando el Tribunal Constitucional que la celebración de juicios abreviados anteriores en nada vinculaba al Tribunal de Juicio Oral en lo Penal en lo que debía resolver a futuro ${ }^{116}$. Resulta interesante apuntar que el mismo acusado, una vez que fue condenado, recurrió nuevamente de inaplicabilidad invocando la inconstitucionalidad de otros preceptos $^{117}$, quedando claro que en el juicio oral el Ministerio Público ni ninguno de los restantes querellantes ofreció como prueba los antecedentes referidos a los juicios abreviados celebrados con los restantes imputados.

\footnotetext{
115 En la sentencia del caso Jesús Manzur Saca (2011) se consignan las siguientes alegaciones del recurrente: "señalan así que se ha elegido a su representado para ser 'coronado' en un juicio oral, al cual el fiscal llegará premunido de 4 sentencias condenatorias firmes que dan por establecidos los hechos materia del proceso (...) no siempre el juicio oral y público será la mejor garantía del debido proceso, pues, en este caso, los hechos están reconocidos por los otros imputados ya condenados en cuatro procedimientos abreviados (...) y al estar reconocidos los hechos por otros imputados ya condenados, el requirente queda sin posibilidad real de controvertirlos, situación que es particularmente grave en la medida que su línea de defensa apunta además a que los hechos no son constitutivos de los delitos. A ello hay que agregar que los demás imputados sindicaron al requirente como partícipe de los mismos (...) se verá afectado por las sentencias condenatorias que dan por establecidos los hechos y los califican como delito". Es paradójico que ninguna de las partes como tampoco el Tribunal Constitucional hayan siquiera mencionado el art. 335 CPP, que posiblemente hubiera resuelto el problema de forma más clara. El Ministerio Público en sus descargos escritos dijo que "no es efectivo que las condenas de los otros imputados influyan en la situación procesal del señor Manzur Saca, porque, en la medida que la ley permite la separación de procesos, el acusado puede esgrimir todos los argumentos que considere necesarios para su defensa". El Consejo de Defensa del Estado señaló a su turno que "la utilización de las sentencias de los otros juicios abreviados no afecta al requirente, pues en el juicio oral puede controvertir los hechos, como ha ocurrido en otros casos". El recurrente había señalado en su requerimiento que "son remotas las posibilidades de que en un juicio oral se contravenga una anterior sentencia (la del procedimiento abreviado aplicado a los demás coimputados) pasada con autoridad de cosa juzgada".

116 En el voto de minoría se señaló, sin embargo, que "la obtención de esta confesión [del imputado para acogerse al juicio abreviado] independiente de la licitud constitucional de los procedimientos empleados para ello, especialmente en la etapa desformalizada de la investigación, invade la esfera jurisdiccional, pues la confesión es un medio de prueba que sólo puede ser producida por medios o ante instancias jurisdiccionales. La confesión extrajudicial desde tiempos inmemoriales, en los albores del constitucionalismo, no tiene valor jurisdiccional en sí misma y su práctica por los investigadores en cualquier ordenamiento jurídico civilizado está revestida de resguardos tales que no se divisan en el cuerpo legal al que pertenece el precepto impugnado en la especie".
}

117 Rol No 2416/2013-INA. 
Recapitulando, puede decirse que: (i) el Ministerio Público goza de la facultad discrecional de solicitar la celebración de un juicio abreviado con parte de los coimputados en una misma investigación, y no tiene la obligación de hacerlo con todos; y que (ii) en principio, los antecedentes referidos a esos juicios abreviados, incluida la declaración del condenado por esa vía, pueden hacerse valer como prueba en juicio oral en contra de un coimputado por el mismo hecho ya condenado, de acuerdo a una interpretación estricta del art. 335 CPP y a lo resuelto por el Tribunal Constitucional.

En todo caso, la decisión adoptada por el legislador chileno me parece criticable, por las razones expuestas, debiendo haberse consagrado una solución similar a la de la ley procesal argentina y española.

\section{En el proceso civil}

La pregunta que debe formularse a continuación es qué valor probatorio tendrán las sentencias condenatorias de los coimputados en juicio abreviado, en un juicio indemnizatorio diverso iniciado por la querellante en contra de aquel que no fue objeto de esa salida alternativa, y prefirió someterse al juicio oral. Si el coimputado que decidió ser juzgado en juicio oral resulta absuelto o sobreseído definitivamente, debiera aplicarse con preferencia la regla del art. 179 CPC, en el evento que concurran las causales contempladas en la misma para que la absolución o sobreseimiento produzcan efecto de cosa juzgada civil ${ }^{118}$. Si no concurren esas causales y, por lo tanto, la absolución o sobreseimiento definitivo no produce cosa juzgada civil, las sentencias condenatorias de los coimputados en juicio abreviado no tendrán el valor de cosa juzgada, ya que no se aplicará el art. 178 CPC, por las razones ya apuntadas en el capítulo V de este trabajo. Tampoco podrían valer como una confesión extrajudicial, ya que no se trata de una parte en el proceso, sino de un tercero y, por lo mismo, no serviría como una posible plena prueba. La solución sería incorporar esa

\footnotetext{
118 "Art. 179. Las sentencias que absuelvan de la acusación o que ordenen el sobreseimiento definitivo, sólo producirán cosa juzgada en materia civil, cuando se funden en alguna de las circunstancias siguientes: $1^{\mathrm{a}}$ La no existencia del delito o cuasidelito que ha sido materia del proceso. No se entenderán comprendidos en este número los casos en que la absolución o sobreseimiento provengan de la existencia de circunstancias que eximan de responsabilidad criminal; $2^{\text {a }}$ No existir relación alguna entre el hecho que se persigue y la persona acusada, sin perjuicio de la responsabilidad civil que pueda afectarle por actos de terceros, o por daños que resulten de accidentes, en conformidad a lo establecido en el Título XXXV, Libro IV, del Código Civil; y $3^{\text {a }}$ No existir en autos indicio alguno en contra del acusado, no pudiendo en tal caso alegarse la cosa juzgada sino respecto de las personas que hayan intervenido en el proceso criminal. Las sentencias absolutorias o de sobreseimiento en materia criminal relativas a los tutores, curadores, albaceas, síndicos, depositarios, tesoreros y demás personas que hayan recibido valores u objetos muebles por un título de que nazca obligación de devolverlos, no producirán en ningún caso cosa juzgada en materia civil".
} 
sentencia como un instrumento público en el proceso civil, y como testigos las declaraciones de los condenados en juicio abreviado.

\section{Conclusiones}

1. La pregunta que se intenta responder en este trabajo se refiere al valor que debe asignársele en el proceso indemnizatorio por responsabilidad civil ex delicto, a la sentencia condenatoria penal del juicio abreviado y simplificado en que existió admisión de responsabilidad por parte del imputado. Esto, porque la entrada en vigencia del CPP no significó una adecuación de la legislación civil respectiva, la que mantuvo inmutable el art. 178 CPC, que permite hacer valer -con efecto de cosa juzgada, según la doctrina- la sentencia condenatoria penal en el proceso civil.

2. El juicio abreviado y el simplificado en que existe admisión de responsabilidad, son figuras que tienen su correspondencia en el derecho comparado, donde han sido objeto de consistentes críticas por parte de la doctrina. En particular, puede decirse que no resultan una vía idónea para el descubrimiento de la verdad, ya que adolecen de tres déficits: las partes conocen de antemano cómo concluirá el proceso, no existe una confrontación entre dos versiones contrapuestas, y tampoco existe un pronunciamiento jurisdiccional sobre el fondo. Esto, en el entendido que es posible determinar la verdad en el proceso penal, aun cuando la verdad que interesa al proceso viene limitada por la descripción típica, el respeto de las garantías del imputado en la obtención y rendición de las pruebas, la presunción de inocencia, y la cosa juzgada, esta última, como impedimento a revisar la verdad de lo acaecido una vez que existe sentencia firme.

3. No siendo una vía idónea de descubrimiento de la verdad, la sentencia condenatoria pronunciada en juicio abreviado o simplificado en que existió admisión de responsabilidad, no puede hacerse valer en el juicio civil de responsabilidad ex delicto, sin perjuicio de que la admisión de hechos efectuada por el imputado podrá servir como una confesión extrajudicial, de acuerdo a la norma del art. 398 CPC.

4. Respecto de los casos con pluralidad de imputados, parece no existir impedimento legal ni jurisprudencial en el sentido de que sólo alguno de los imputados se acojan al juicio abreviado, y otros sean llevados a juicio oral por el Ministerio Público, utilizándose como prueba las sentencias del abreviado en el juicio oral posterior. Sin embargo, tratándose de un proceso civil posterior por responsabilidad ex delicto, no podría hacerse valer como confesión extrajudicial la admisión de hechos efectuada por otro imputado, al no cumplirse con el requisito de la norma del art. 398 CPC, de que el juicio penal debió haber sido entre las mismas partes. 
BiBLIOGRAFíA CITADA

Alessandri, Arturo; Somarriva, Manuel; y Vodanovic, Antonio (1998): Tratado de Derecho Civil. Partes preliminar y general. Tomo II (Editorial Jurídica de Chile).

AllorIo, Enrico (2014): La cosa juzgada frente a terceros (Madrid, Editorial Marcial Pons).

Anabalón, Carlos (1963): Tratado práctico de Derecho procesal civil chileno. Tomo Tercero. El juicio ordinario de mayor cuantía (Santiago, Arancibia Hermanos Editores).

ARMENTA, Teresa (2012): Sistemas procesales penales. La justicia penal en Europa y América. (Madrid, Editorial Marcial Pons).

ARMENTA, Teresa (2013): "Algunas reflexiones en torno a la convergencia entre los procesos civil y penal y la deriva común hacia métodos extrajurisdiccionales", en ArmentA, Teresa (coord.), La convergencia entre el proceso civil y penal ¿una dirección adecuada? (Madrid, Editorial Marcial Pons).

Austin, John (2014): Cómo hacer cosas con palabras (Barcelona, Editorial Paidós).

BARONA, Silvia (1994): La conformidad en el proceso penal (Barcelona, Editorial Tirant lo Blanch).

BARROS, Enrique (2008): Tratado de responsabilidad extracontractual (Editorial Jurídica de Chile).

Bertolino, Pedro (1999): "Para un encuadre del proceso penal abreviado", en Revista de Derecho y Jurisprudencia, (Tomo XCVI № 1), pp. 1-21.

BIGLIANI, Paola (2005): “El juicio abreviado y su recepción en el orden jurídico argentino", en Maler, Julio y Bovino, Alberto (comps.), El procedimiento abreviado (Buenos Aires, Editores del Puerto).

Bovino, Alberto (2005): "Procedimiento abreviado y juicio por jurados", en MAIER, Julio y Bovino, Alberto (comps.), El procedimiento abreviado (Buenos Aires, Editores del Puerto).

Cafferata, José Ignacio (1997): Cuestiones actuales sobre el proceso penal (Buenos Aires, Editores del Puerto).

Calamandrei, Piero (1945): "El proceso como juego", en Estudios sobre el proceso civil (Buenos Aires, Editorial Bibliográfica Argentina).

Carocca, Alex (2006): "Algunas consideraciones sobre los efectos de las sentencias penales absolutorias en los procesos civiles", en Revista Procesal Penal (No 54), pp. 35-48.

Casarino, Mario (2005): Manual de Derecho Procesal. Derecho procesal civil. Tomo III (Editorial Jurídica de Chile). 
CociÑA, Martina (2012): La verdad como finalidad del proceso penal (Santiago, Editorial Thomson Reuters).

Colombo, Juan (2014): Los actos procesales. Tomo I (Santiago, Editorial Jurídica de Chile).

CONTARDO, Juan Ignacio (2015): Indemnización y resolución por incumplimiento (Santiago, Editorial Thomson Reuters).

Córdoba, Gabriela (2005): “El juicio abreviado en el Código Procesal Penal de la Nación", en MAIER, Julio y Bovino, Alberto (comps.), El procedimiento abreviado (Buenos Aires, Editores del Puerto).

CorduA, Carla (2013): Wittgenstein (Santiago, Ediciones Universidad Diego Portales).

CORRAL, Hernán (2013): Lecciones de responsabilidad civil extracontractual. Segunda edición actualizada (Santiago, Editorial Thomson Reuters).

Couture, Eduardo (2014): Fundamentos del Derecho Procesal Civil. Cuarta edición (Buenos Aires, Editorial B de F).

Dé Río, Carlos (2008): "El principio del consenso de las partes en el proceso penal y enjuiciamiento jurisdiccional: aclaraciones conceptuales necesarias", en Revista Chilena de Derecho (vol. 35, № 1), pp. 157-182.

Dewey, Matías (2008): "Procedimientos fallidos: disposición al riesgo y legitimación de expectativas normativas en Argentina", en Revista de Sociología de la Facultad de Ciencias Sociales de la Universidad de Chile ( $\left.\mathrm{N}^{\circ} 22\right)$, pp. 193-216.

Díaz, Fernando (2005): "Juicio abreviado vs. Estado de Derecho", en MAIER, Julio y Bovino, Alberto (comps.), El procedimiento abreviado (Buenos Aires, Editores del Puerto).

DucE, Mauricio, y RııGo, Cristián (2009): Proceso penal (México, Editorial Jurídica de las Américas).

FALCONE, Diego (2005): "La absolución en el procedimiento abreviado", Revista de Derecho de la Pontificia Universidad Católica de Valparaíso, № XXVI.

Ferrajol, Luigi (2005): “Las lesiones legales del modelo constitucional del proceso penal", en MAIER, Julio y Bovino, Alberto (comps.), El procedimiento abreviado (Buenos Aires, Editores del Puerto).

FerRAJOLI, Luigi (2009): Derecho y razón. Teoría del garantismo penal (Madrid, Editorial Trotta).

Foucault, Michel (2000): La verdad y las formas jurídicas (Barcelona, Editorial Gedisa).

Garner, Bryan (2004): Black's Law Dictionary. Eighth Edition (Estados Unidos de América, Editorial Thomson West). 
Gimeno Sendra, Vicente (2010): Manual de Derecho procesal penal (Madrid, Editorial Colex).

González Lagier, Daniel (2013): "Presunción de inocencia, verdad y objetividad", en García Amado, Juan Antonio y Bonorino, Pablo Raúl (coords.), Prueba y razonamiento probatorio en Derecho. Debates sobre abducción (Granada, Editorial Comares).

Grande, Pablo (2008): La extensión subjetiva de la cosa juzgada en el proceso civil (Valencia, Editorial Tirant lo Blanch).

GuZmán, Nicolás (2005): "La verdad y el procedimiento abreviado", en MAIER, Julio y Bovino, Alberto (comps.), El procedimiento abreviado (Buenos Aires, Editores del Puerto).

HACKING, Ian (2005): El surgimiento de la probabilidad. Un estudio filosófico de las ideas tempranas acerca de la probabilidad, la inducción y la inferencia (Barcelona, Editorial Gedisa).

HASSEMER, Winfried (1984): Fundamentos del Derecho Penal (Barcelona, Editorial Bosch).

HASSEMER, Winfried (2009): La verdad y la búsqueda de la verdad en el proceso penal. La medida de la Constitución (México, Editorial Ubijus).

Horvitz, María Inés (2004a): Derecho procesal penal chileno. Tomo I (Editorial Jurídica de Chile).

Horvitz, María Inés (2004b): Derecho procesal penal chileno. Tomo II (Editorial Jurídica de Chile).

Krause, Soledad (2015): Responsabilidad: lo unitario en los sistemas civil y penal (Santiago, Editorial Thomson Reuters).

LANGeR, Máximo (2005): “Dicotomía acusatorio-inquisitivo y tradición jurídica anglosajona", en MAIER, Julio y Bovino, Alberto (comps.), El procedimiento abreviado (Buenos Aires, Editores del Puerto).

LANGBEIN, John (2005): "Tortura y plea bargaining", en MAIER, Julio y Bovino, Alberto (comps.), El procedimiento abreviado (Buenos Aires, Editores del Puerto).

Lazo, Santiago (1918): Los Códigos chilenos anotados. Orígenes, concordancias y jurisprudencia del Código de Procedimiento Civil (Santiago, Poblete Cruzat Hermanos Editores).

LieBMAN, Enrico (1946): Eficacia y autoridad de la sentencia y otros estudios sobre la cosa juzgada (con adiciones relativas al Derecho brasileño) (Buenos Aires, Editorial Ediar S.A.).

Lozano, Marta (2012): "Conformidad y pluralidad de acusados", en Revista de Derecho UNED (No 10), pp. 347-365. 
LUHMANN, Niklas (2013): Legitimation durch Verfahren (Alemania, Editorial Suhrkamp Verlag GmbH).

MAIER, Julio (1989): Derecho procesal penal argentino. Tomo I vol. b. Fundamentos (Buenos Aires, Editorial Hammurabi).

MaIER, Julio (1999): Derecho procesal penal tomo I, Fundamentos (Buenos Aires, Editores del Puerto).

Mallord, Joel (2014): "Plea bargaining on the record", en University of Pennsylvania Law Review (vol. 162 № 3), pp. 683-718.

MaÑalıCH, Juan Pablo (2011): "El principio ne bis in idem en el Derecho penal chileno", en Revista de Estudios Judiciales (№ 15), pp.139-169.

MaÑALICH, Juan Pablo (2014): "El principio ne bis in idem frente a la superposición del derecho penal y el derecho administrativo sancionatorio", en Revista Política Criminal (Volumen 9, № 18), pp. 543-563.

Marín, Juan Carlos (2005): "La acción civil en el nuevo Código Procesal Penal chileno: su tratamiento procesal", en Revista de Estudios de la Justicia ( $\left.\mathrm{N}^{\circ} 6\right)$, pp. 11-44.

MARTíN PASTOR, José (2013): "Algunas manifestaciones de la aproximación entre el proceso penal y el proceso civil", en ARMENTA, Teresa (coord.), La convergencia entre el proceso civil y penal ¿una dirección adecuada? (Madrid, Editorial Marcial Pons).

Maturana, Cristián (2009): Reforma Procesal Penal. Génesis, historia sistematizada y concordancias. Tomo III: Código Procesal Penal, Libro tercero y cuarto (México, Editorial Jurídica de las Américas).

MıLL, John Stuart (2009): Sobre la libertad (España, Alianza Editorial).

MontaÑez, Julio César (2013): "Las negociaciones en el proceso penal: del procedimiento inquisitivo a la prisionización masiva", Revista Derecho Penal y Criminología (vol. 34, № 97), pp. 65-83.

Montero Aroca, Juan (2011): La prueba en el proceso civil. Séptima edición (Navarra, Editorial Thomson Reuters Civitas).

NIEVA, Jordi (2006): La cosa juzgada (Barcelona, Editorial Atelier).

Nieva, Jordi (2012): Fundamentos de Derecho Procesal Penal (Buenos Aires, Editorial Edisofer).

NIEVA, Jordi (2013): La duda en el proceso penal (Madrid, Editorial Marcial Pons).

Núñez, Juan Cristóbal (2003): Tratado del proceso penal y del juicio oral. Los procedimientos especiales y la ejecución de la sentencia (Editorial Jurídica de Chile).

Paillás, Enrique (1979): Estudios de derecho probatorio (Editorial Jurídica de Chile). 
Pereira, Hugo (1984): "Fundamento constitucional de la cosa juzgada", en Revista de Derecho de la Universidad de Concepción (№ 175), pp. 29-40.

PINOCHET, Ruperto (2008): "El valor de las sentencias condenatorias penales del nuevo derecho procesal penal en materia civil", en Revista de Actualidad Jurídica de la Universidad del Desarrollo (No 18), pp. 299-331.

PiñA, Juan Ignacio (2014): Derecho penal. Fundamentos de la responsabilidad (Santiago, Editorial Thomson Reuters).

Pizarro, Carlos (2005): "Mirada de un civilista a la reparación en el nuevo proceso penal", en Gaceta Jurídica (№ 296), pp. 59-75.

RaGués IVAllés, Ramón (1999): El dolo y su prueba en el proceso penal (Barcelona, J.M. Bosch Editor).

Rawls, John (2012): Teoría de la justicia (México, Fondo de Cultura Económica). RIED, Ignacio (2015): “El efecto de cosa juzgada de la sentencia penal absolutoria y del sobreseimiento definitivo en el proceso chileno de responsabilidad civil", en Revista Chilena de Derecho Privado, (№ 24), pp. 9-57.

RieGo, Cristián (2005): "El procedimiento abreviado en Chile", en Maier, Julio y Bovino, Alberto (comps.), El procedimiento abreviado (Buenos Aires, Editores del Puerto).

RodríGueZ, Nicolás (1995): "Aproximación al estudio de la justicia penal negociada en los EE.UU.: the plea bargaining process", en Revista Española de Estudios Norteamericanos ( $\mathrm{N}^{\circ}$ 9), pp. 91-107.

Rodríguez, Gabriela (2005): "El ethos de las decisiones penales: verdad real y consenso", en Revista de Ciencias Sociales Aposta (№ 22), pp. 1-24.

ROMero Coloma, Aurelia María (2009): El interrogatorio del imputado y la prueba de confesión (Madrid, Editorial Reus, Colección Scientia luridica).

Romero, Alejandro (2011): La cosa juzgada en el derecho procesal civil chileno. Doctrina y jurisprudencia (Editorial Jurídica de Chile).

Romero, Alejandro (2012): "La sentencia judicial como medio de prueba", en Revista Chilena de Derecho (Vol. 39, № 2), pp. 251-276.

Romero, Alejandro (2015): "La prejudicialidad en el proceso civil", en Revista Chilena de Derecho (Vol. 41, № 2), pp. 453-482.

Rosende, Cecilia (2001): "Efectos directos y reflejos de la sentencia", en Revista Chilena de Derecho (Vol. 28 № 3), pp. 489-502.

Rojas, Julio (2013): "Efectos reflejos de la sentencia condenatoria contra el imputado hacia los terceros civilmente responsables en el derecho procesal chileno", disponible en http://www.lexweb.cl/tag/juliorojaschamaca.

Roxin, Claus (2001): Derecho procesal penal (Buenos Aires, Editores del Puerto). 
SAlas, Jaime (2015): Problemas del proceso penal. Investigación, etapa intermedia y procedimientos especiales. Segunda edición aumentada (Santiago, Editorial Librotecnia).

Serra, Manuel (1969): "Contribución al estudio de la prueba", en Estudios de Derecho procesal (Barcelona, Ariel).

Sııva, Jesús-María (2011): "Caso Filesa", en Sánchez-Ostiz, Pablo (coord.), Casos que hicieron doctrina en Derecho penal (Madrid, Editorial La Ley).

TARUfFO, Michele (2006): "El proceso de 'civil law': aspectos fundamentales", en Revista lus et Praxis de la Universidad de Talca (Vol. 12 № 1), pp. 69-94.

TARUFFO, Michele (2010): Simplemente la verdad. El juez y la construcción de los hechos (Madrid, Editorial Marcial Pons).

TARUFFO, Michele (2012): Consideraciones sobre la prueba y motivación de la sentencia civil (Santiago, Editorial Metropolitana).

TonINI, Paolo (2015): Manuale di procedura penale (Milano, Editorial Giuffre).

VIVAS, Gustavo (1993): "La confesión transaccional y el juicio abreviado", en VV.AA. Estudios sobre el nuevo Código Procesal Penal de Córdoba (Córdoba, Editorial Lerner).

WittGenstein, Ludwig (2012): Investigaciones filosóficas (Barcelona, Editorial Crítica). Barcelona.

Wittgenstein, Ludwig (2014): Tractatus logico-philosophicus (Madrid, Alianza Editorial).

\section{JURISPRUDENCIA CITADA}

Jorge Lavandero Illanes (2005a): Juzgado de Garantía de Temuco, RIT 4150-2004, de 25 de junio de 2005 (aprobación de juicio abreviado).

Jorge Lavandero Illanes (2005b): Corte de Apelaciones de Temuco, NIC 5322005, de 16 de julio de 2005 (apelación de aprobación de juicio abreviado).

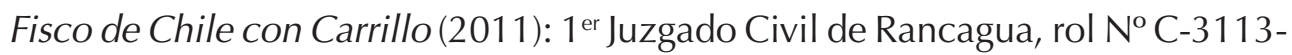
2009, de 16 de mayo de 2011 (sentencia definitiva de primera instancia).

Jesús Manzur Saca (2011): Tribunal Constitucional, rol № 1481-09-INA, de 10 de mayo de 2011 (requerimiento de inaplicabilidad por inconstitucionalidad).

Roblin con Esquivel (2011): Corte de Apelaciones de Valparaíso, NIC 473-2011, de 23 de junio de 2011 (apelación de sentencia definitiva civil).

Consejo de Defensa del Estado con De Geyte (2013): Corte Suprema, rol № 3444-2013, de 14 de octubre de 2013 (casación en la forma).

Domínguez con Donoso y otro (2014): $18^{\circ}$ Juzgado Civil de Santiago, rol $\mathrm{N}^{\circ} \mathrm{C}-14664-2012$, de 7 de julio de 2014 (sentencia definitiva de primera instancia). 
Eugenio Domínguez Delpiano y otros (2015): Tribunal Constitucional, rol $N^{\circ}$ 2799-2015-INA, de 24 de diciembre de 2015 (sentencia en requerimiento de inaplicabilidad por inconstitucionalidad).

NORMAS CITADAS

Constitución Política de la República

Código Civil

Código Penal

Código de Procedimiento Civil

Código Procesal Penal

Código de Procedimiento Penal

Ley de Enjuiciamiento Penal española

Código Procesal Penal de la Nación Argentina

Federal Rules of Criminal Procedure de los Estados Unidos de América

Código Procesal Penal Modelo para Iberoamérica 